\title{
Lithospheric structures and Precambrian terrane boundaries in northeastern Botswana revealed through magnetotelluric profiling as part of the Southern African Magnetotelluric Experiment
}

M. P. Miensopust, ${ }^{1,2}$ A. G. Jones, ${ }^{1}$ M. R. Muller, ${ }^{1}$ X. Garcia, ${ }^{3}$ and R. L. Evans ${ }^{4}$

Received 10 June 2010; revised 16 October 2010; accepted 22 November 2010; published 3 February 2011.

[1] Within the framework of the Southern African Magnetotelluric Experiment a focused study was undertaken to gain improved knowledge of the lithospheric geometries and structures of the westerly extension of the Zimbabwe craton (ZIM) into Botswana, with the overarching aim of increasing our understanding of southern African tectonics. The area of interest is located in northeastern Botswana, where Kalahari sands cover most of the geological terranes and very little is known about lithospheric structures and thicknesses. Some of the regional-scale terrane boundary locations, defined based on potential field data, are not sufficiently accurate for local-scale studies. Investigation of the NNW-SSE orientated, $600 \mathrm{~km}$ long ZIM line profile crossing the Zimbabwe craton, Magondi mobile belt, and Ghanzi-Chobe belt showed that the Zimbabwe craton is characterized by thick $(\sim 220 \mathrm{~km})$ resistive lithosphere, consistent with geochemical and geothermal estimates from kimberlite samples of the nearby Orapa and Letlhakane pipes $(\sim 175 \mathrm{~km}$ west of the profile). The lithospheric mantle of the Ghanzi-Chobe belt is resistive, but its lithosphere is only about $180 \mathrm{~km}$ thick. At crustal depths a northward dipping boundary between the Ghanzi-Chobe and the Magondi belts is identified, and two middle to lower crustal conductors are discovered in the Magondi belt. The crustal terrane boundary between the Magondi and Ghanzi-Chobe belts is found to be located further to the north, and the southwestern boundary of the Zimbabwe craton might be further to the west, than previously inferred from the regional potential field data.

Citation: Miensopust, M. P., A. G. Jones, M. R. Muller, X. Garcia, and R. L. Evans (2011), Lithospheric structures and Precambrian terrane boundaries in northeastern Botswana revealed through magnetotelluric profiling as part of the Southern African Magnetotelluric Experiment, J. Geophys. Res., 116, B02401, doi:10.1029/2010JB007740.

\section{Introduction}

[2] From 2003 to 2008 magnetotelluric (MT) data were acquired at hundreds of sites in South Africa, Botswana and Namibia (see Figure 1). The aim of this project, the Southern African Magnetotelluric Experiment (SAMTEX), is to improve the understanding of the southern African geological framework and the history of tectonic processes involved in the formation of the southern part of the continent, and MT is being used to map lithospheric structures and geometries of various terranes. The focus of the work presented herein is an area in northeastern Botswana, where most of the geological

\footnotetext{
${ }^{1}$ Geophysics Section, School of Cosmic Physics, Dublin Institute for Advanced Studies, Dublin, Ireland.

${ }^{2}$ Department of Earth and Ocean Sciences, National University of Ireland, Galway, Ireland.

${ }^{3}$ Unitat de Tecnologia Marina, CSIC, Barcelona, Spain.

${ }^{4}$ Department of Geology and Geophysics, Woods Hole Oceanographic Institution, Woods Hole, Massachusetts, USA.

Copyright 2011 by the American Geophysical Union. 0148-0227/11/2010JB007740
}

terranes are covered by thick Kalahari sands. Only a few outcrops and magnetic and gravity surveys are available to allow the determination of the approximate outlines of these terranes. The only information about lithospheric mantle structure in northeastern Botswana is provided by xenoliths from the kimberlites of the Orapa and Letlhakane pipes ("O" and " $L$ " in Figure 1). It is uncertain which geological terrane these pipes belong to, as they are located on the boundary (based on the potential field data) between the Magondi Mobile Belt and the Zimbabwe craton (ZIM). About 150 $200 \mathrm{~km}$ to the east of these pipes the so-called ZIM line is located. This NNW-SSE orientated, $600 \mathrm{~km}$ long 2-D MT profile crosses the Zimbabwe craton, the Magondi Mobile Belt and the Ghanzi-Chobe Belt.

[3] Prior to SAMTEX work, northeastern Botswana has been mostly terra incognita, especially at lithospheric mantle depths. For none of the terranes was the thickness of the lithosphere known, nor the location or nature (e.g., sharp or smooth transition, dip, different location at crustal than lithospheric mantle depths) of the terrane boundaries at lithospheric mantle depths. While the terrane boundaries drawn based on the potential field data [Webb, 2009] provide a 


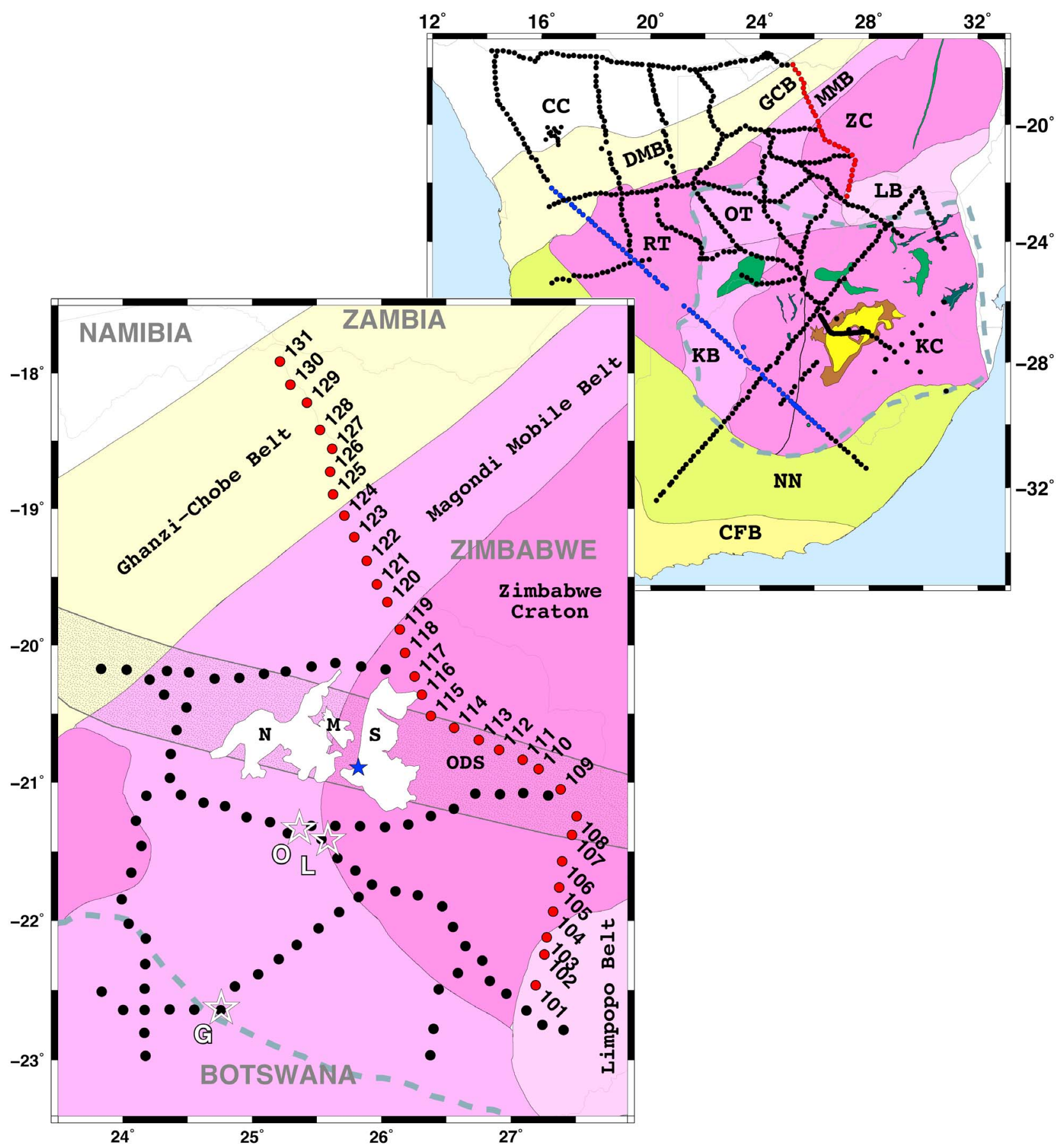

Figure 1. Rough outline of the geological provinces and main structures of southern Africa (digital terrane boundaries courtesy of Susan J. Webb, University of the Witwatersrand, Johannesburg, South Africa, based on known geology in South Africa and Zimbabwe and primarily on interpretation of potential field data in Namibia and Botswana, where thick Kalahari sands cover basement [see also Webb, 2009]). The gray dashed line indicates the outline of the Kaapvaal craton given by Eglington and Armstrong [2004]. The black circles represent all SAMTEX site locations, with the ZIM line highlighted in red and the KIM-NAM line highlighted in blue. The Makgadikgadi salt pan complex is indicated by the white lake-like feature (M, Makgadikgadi pan; N, Ntwetwe pan; S, Sua pan); the blue star represents the location of Kubu Island; and the white stars show the locations of the Gope $(\mathrm{G})$, Letlhakane (L), and Orapa (O) kimberlite pipes. The giant mafic Okavango Dike Swarm (ODS)is indicated by the gray-shaded area; the Witwatersrand Basin is shown in yellow and brown; the Greenstone belts are represented in green; and the Bushveld complex, Molopo Farms, and Trompsburg are in dark green (CC, Congo craton; CFB, Cape fold belt; DMB, Damara mobile belt; GCB, Ghanzi-Chobe belt; KB, Kheis belt; KC, Kaapvaal craton; LB, Limpopo belt; MMB, Magondi mobile belt; NN, Namaqua-Natal belt; OT, Okwa terrane; RT, Rehoboth terrane; ZC, Zimbabwe craton). 
regional-scale picture, our MT data provide an opportunity to examine the nature and position of the boundaries in greater detail.

[4] MT can be used to determine the resistivity structure of the subsurface and thus provides useful information that helps to improve the understanding of complex structures and the tectonic evolution of a region [e.g., Jones and Craven, 1990; Jones et al., 2002, 2005a; Evans et al., 2005; Spratt et al., 2009]. MT is able to detect regions of enhanced conductivity (reduced resistivity) at crustal and lithospheric mantle depths (caused by a number of mechanisms, e.g., graphite or carbon films, fluids, partial melts, sulphides [e.g., Schwarz, 1990; Nover et al., 1998]) but can also map the thickness of the lithosphere [Jones, 1999]. MT can also define structures based on electrical anisotropy, and comparisons between electrical and seismic anisotropy directions have been enlightening [e.g., Ji et al., 1996; Eaton et al., 2004; Hamilton et al., 2006; Padilha et al., 2006].

\section{Tectonic and Geological Setting}

[5] Continental fragments formed before $2.5 \mathrm{Ga}$ are known as Archean cratons. These cratons can be found worldwide [Kusky and Polat, 1999]. Bleeker [2003] recently categorized 35 cratons on all continents (e.g., in Canada, USA, Scandinavia, Australia and southern Africa) and two of them, the Kaapvaal craton (formed and stabilized between 3.7 and $2.7 \mathrm{Ga}$ [de Wit et al., 1992]) and the Zimbabwe craton (3.5 Ga to $2.6 \mathrm{Ga}$ [Kusky, 1998; Horstwood et al., 1999]), form the core of the southern African continent and are known together as the Kalahari craton (also known as Proto-Kalahari craton [e.g., Jacobs et al., 2008]). Figure 1 shows the approximate outlines of the Kaapvaal and the Zimbabwe cratons including their surrounding mobile belts and the granite-greenstone belts of the Kaapvaal craton.

[6] The Kaapvaal and the Zimbabwe cratons collided at about 2.7-2.6 Ga, and the collision formed the Limpopo belt in between [van Reenen et al., 1987]. These three Archean regions are bounded to the northwest by the Paleoproterozoic Kheis belt (believed to be underlain by lithosphere that is part of the Kaapvaal craton [Tinker et al., 2004; de Wit and Tinker, 2004]), Okwa terrane (inferred to form part of the Kaapvaal craton [Eglington and Armstrong, 2004; Corner, 2008]) and the Magondi belt. To the northwest of these belts are the Ghanzi-Chobe belt (northeast Botswana) and the Damara belt (Namibia and northwest Botswana). The latter belt stabilized after the Damara orogen, that records the Gondwanan assembly of the Congo-Kalahari-Rio de la Plata cratons. First, at about 750-600 Ma, the Congo craton and the Rio de la Plata craton (today in South America) collided and accreted, and later (about $550 \mathrm{Ma}$ ) suturing of the Congo and the Kalahari cratons completed the Gondwanan assembly of southern Africa [Prave, 1996].

[7] The three major geological terranes traversed by the ZIM MT profile (red circles in Figure 1 represent the site locations) are the Archean Zimbabwe craton, the Paleoproterozoic Magondi belt and the Mesoproterozoic to Neoproterozoic Ghanzi-Chobe belt. The Zimbabwe craton, formerly the Rhodesian craton, is mainly located in Zimbabwe, but it extends westward into Botswana. The full crustal extent of the Zimbabwe craton into Botswana is unknown, as the western boundary is obscured beneath
Phanerozoic cover rocks and Kalahari sands, and also the southern boundary is ill defined [McCourt et al., 2004]. The configuration of the lithospheric mantle both beneath the craton and on all of its boundaries is also entirely unknown. The oldest rocks in the Zimbabwe craton include tonalitic to granodioritic, locally migmatitic, gneissic rocks with $\mathrm{U}-\mathrm{Pb}$ and $\mathrm{Pb}-\mathrm{Pb}$ ages between $3.5 \mathrm{Ga}$ and $2.95 \mathrm{Ga}$ [Kusky, 1998; Horstwood et al., 1999]. The ancient core of the craton, which was established as a coherent block by $2.95 \mathrm{Ga}$ and consists of greenstone belts and older gneissic rocks, is in many places overlain unconformably by a heterogeneous mix of volcanic and sedimentary rocks regionally known as Lower Greenstones or Lower Bulawayan Group [Wilson, 1979; Kusky, 1998]. Due to the Karoo ( 330-145 Ma) and younger deposits in the Kalahari, the western margin of the Zimbabwe craton, as well as the interpretation of the nature and boundaries of the Proterozoic terranes west of the craton, are obscure [Majaule et al., 2001]. In western Zimbabwe, the craton is bordered to the northwest by the Paleoproterozoic (2.0-1.8 Ga) Magondi belt [Majaule et al., 2001; Leyshon and Tennick, 1988; Treloar, 1988]. Treloar [1988] describes the Magondi belt in Zimbabwe as a product of Paleoproterozoic basinal sedimentation followed by deformation and associated metamorphism on the northwestern margin of the Zimbabwe craton. In the south, the belt is a typical thinskinned thrust belt (thrust onto the Archean Zimbabwe craton), whereas northward the structural style is changing to a more thick-skinned type and the metamorphic grade is increasing from greenschist to granulite facies [Treloar, 1988]. The deformation and metamorphism is of Paleoproterozoic to Mesoproterozoic age, and the rocks are essentially unaffected by the subsequent Pan-African deformation and metamorphism [Treloar, 1988; Treloar and Kramers, 1989]. In Botswana, the Magondi orogenic belt lies completely beneath Phanerozoic cover, but isolated basement exposures form islands on the southwestern edge of Sua pan (the easternmost pan of the Makgadikgadi salt pan complex). The main exposures are at Kubu Island (Figure 1). The exposed granites at Kubu are predominantly dated at about 2.0 Ga by Majaule et al. [2001], who interpreted their results as an indication that Kubu Island lies within the region affected by Paleoproterozoic orogenesis in the Magondi belt, and that Archean crustal components were involved in its petrogenesis. To the northwest of the Magondi belt lies the GhanziChobe belt, sometimes considered to be an early component of the Damara Mobile Belt, which is Mesoproterozoic to Neoproterozoic in age. It is a northeast trending, approximately $500 \mathrm{~km}$ long by $100 \mathrm{~km}$ wide, elongated volcanosedimentary basin in northern Botswana (its extent is deduced from regional aeromagnetic and gravimetric surveys [Reeves, 1985]). Knowledge of the Ghanzi-Chobe belt is very limited, due to the lack of exposure caused by a cover of Cenozoic superficial deposits, called the Kalahari group, which overlie more than $90 \%$ of the Ghanzi-Chobe belt [Modie, 1996]. Modie [1996] suggests that the Ghanzi-Chobe belt represents a failed intracontinental rift basin that developed as part of an extensive, but segmented, linear rift system extending from south central Namibia.

[8] Two near-surface structures affect the MT data measured along the ZIM line, namely the Okavango giant mafic dike swarm and the Makgadikgadi salt pan complex. The Okavango giant dike swarm is part of the large-scale Karoo 
tectonomagmatic framework in southern Africa [e.g., Elburg and Goldberg, 2000; Le Gall et al., 2002, 2005; Jourdan et al., 2004, 2006; Aubourg et al., 2008]. The $110^{\circ} \mathrm{E}$ of north trending giant Okavango dike swarm extends over a $1500 \mathrm{~km}$ strike length through Archean basement terranes and Permo-Jurassic sedimentary sequences. The dikes are mainly coarse-grained dolerites [Elburg and Goldberg, 2000; Aubourg et al., 2008], which are hosted by granites, gneiss and amphibolites in the area of the intersection with the ZIM line [Aubourg et al., 2008]. The majority of the dikes have emplacement ages between $178.4 \pm 1.1$ Ma to $180.9 \pm 1.3 \mathrm{Ma}$ (i.e., "Karoo" in age) but at least $10 \%$ of the dikes included in the swarm are Late Proterozoic in age (850-1700 Ma) [Jourdan et al., 2004]. Le Gall et al. [2005] found that about $70 \%$ of the dikes are within $10^{\circ}$ of parallelism with the $110^{\circ} \mathrm{E}$ of north trend of the swarm envelope. The Karoo dike length ranges from 1 to $18 \mathrm{~km}$, and about $91 \%$ of the dikes are vertical, with the other $9 \%$ within $30^{\circ}$ of vertical. Le Gall et al. [2005] estimated the arithmetic mean dike width to be about $17 \mathrm{~m}$ and the crustal dilatation to be $12.2 \%$ in the area of the ZIM line. To the west of the middle of the ZIM profile is the Makgadikgadi salt pans complex, a large and unusual surface feature $\left(>8400 \mathrm{~km}^{2}\right)$ in northeastern Botswana which occupies a basin that is the lowest point in a drainage system extending from Botswana into Namibia, Angola and Zimbabwe. The pans are the remnants of a once-great Pleistocene aged lake that is estimated to have covered $34,000 \mathrm{~km}^{2}$ at its maximum extent, with a water volume of 500 to $1000 \mathrm{~km}^{3}$ [Grove, 1969]. Since there is no identified outlet for Lake Makgadikgadi, it is assumed that a static state was reached where inflow balanced evaporation. Thus, the lake became increasingly saline with time, providing a source for an extensive brine aquifer beneath that area and today's salt pans.

\section{Magnetotellurics in Northeastern Botswana}

\subsection{Data Acquisition and Processing}

[9] Out of the approximately 740 of MT sites acquired by the SAMTEX project, 31 broadband MT (BBMT) sites lie on the ZIM profile (Figure 1; most southern site is named ZIM101, most northern one is ZIM131). The approximately NNW-SSE profile is about $600 \mathrm{~km}$ long and crosses the western edge of the Zimbabwe craton and the neighboring belts. The sites are at roughly $20 \mathrm{~km}$ intervals. The BBMT sites used Phoenix Geophysics equipment, namely MTU-5 and MTU-5A recording boxes and MTC-50 induction coils, and recorded time series data for 2-3 days in the period range of approximately $0.004 \mathrm{~s}$ to $5,000 \mathrm{~s}$. At each of these BBMT sites, the two horizontal, perpendicular magnetic field components $H_{x}$ and $H_{y}$ were recorded, but the vertical magnetic field component $H_{z}$ was not acquired due to the logistical problems of installing the vertical coil in the very solid, rocky ground. The two horizontal, perpendicular electric field components $E_{x}$ and $E_{y}$ were measured using nonpolarizing $\mathrm{Pb}-\mathrm{PbCl}$ (lead-lead-chloride) electrodes laid out in a cross with typically a $100 \mathrm{~m}$ dipole length.

[10] Modern remote-reference, robust time series processing techniques were applied to these BBMT data. After visual inspection of the time series and removal of bad data sections, MT response curves were produced using the multiremote-referencing Phoenix processing software, which is based on the work by Jones and Jödicke [1984] (Method 6 in the work by Jones et al. [1989]). Good quality data were obtained to at least $1000 \mathrm{~s}$ for most sites, and for some sites out to 2000-3000 s (especially at sites at the northern end of the profile). The Niblett-Bostick depth approximation [Niblett and Sayn-Wittgenstein, 1960; Bostick, 1977; Jones, 1983a] was applied to the data of each site to estimate the maximum depth of penetration. This approach is based on a $1-\mathrm{D}$ estimation method but is also largely valid if both 2-D modes, transverse electric (TE) and transverse magnetic (TM) modes, are fully decoupled and penetrate to the same depth as signals in a 1-D structure [Jones, 2006]. Despite the approximate validity of such an approach to estimate depth of penetration especially where the TM and TE modes may not be fully decoupled due to 3-D effects, it is superior to an analysis based on periods. Figure 2 illustrates how variable the maximum penetration depths are; the longest-period data from some sites cannot be associated with depths greater than the base of the crust, whereas the longest-period data at other sites have penetration depths deep into the lithospheric mantle, and in cases sublithospheric mantle. One can also see that at neighboring sites up to 2 orders of magnitude difference in period is required for the same penetration depth, and for some sites (e.g., ZIM106, ZIM121) a difference is apparent between the penetration depths of the two modes.

\subsection{Decomposition and Strike Analysis}

[11] The distortion decomposition code developed by McNeice and Jones [2001], based on the Groom-Bailey decomposition [Bailey and Groom, 1987; Groom, 1988; Groom and Bailey, 1989], was applied to the MT response estimates for each site along the profile to analyze galvanic distortions present and to determine the most consistent geoelectric strike direction over most sites and most periods. Due to the strongly varying penetration depths along the profile, a multisite, multifrequency decomposition based on frequency bands could not be applied to the ZIM line data, compared to, e.g., the work of Spratt et al. [2009]. The strong variation of penetration depth along the profile at the same period made such an approach meaningless, and required a depth-related method. The latest version of the distortion decomposition strike code of McNeice and Jones [2001] allows for a choice of data from different sites based on a depth-band selection (based on the Niblett-Bostick depth approximation applied to the so-called rotationally invariant Berdichevsky, or arithmetic, average MT responses [Berdichevsky and Dmitriev, 1976]). Applying this version of strike to various subsets of the ZIM line data set showed that the geoelectric strike varies not only along the profile but also with depth (see Figure 3). Whereas sites ZIM107 to ZIM114, which are located on top of the Okavango dike swarm, show a geoelectric strike direction of about $110^{\circ} \mathrm{E}$ of north at all depths (i.e., parallel, or perpendicular due to the $90^{\circ}$ ambiguity in strike direction, to the orientation of the dike swarm), all the other sites conform to approximately $55^{\circ} \mathrm{E}$ of north at crustal depths and $35^{\circ} \mathrm{E}$ of north at lithospheric mantle depths. Most of the data, despite high twist and shear values indicating strong distortion at some sites, are consistent with a 1-D or 2-D regional resistivity structure, as the 2-D decomposition models fit the data to within prescribed errors (either actual errors or errors of $3.5 \%$ in the maximum impedance, which is $7 \%$ in the largest apparent resistivity and $2^{\circ}$ in phase 


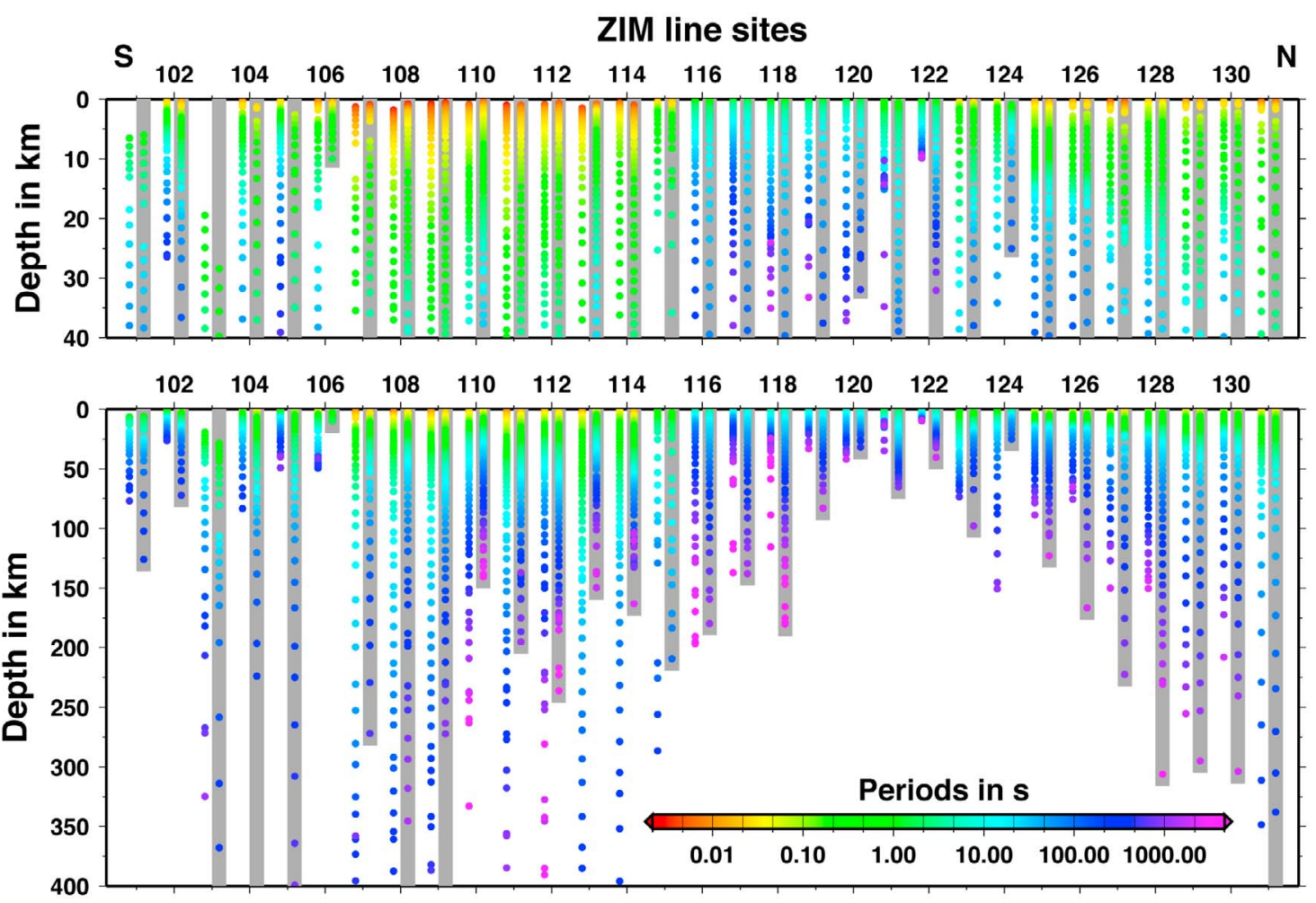

Figure 2. Niblett-Bostick penetration depths for all sites on the ZIM line. Each colored circle represents a measurement at a certain period and depth with the color indicating the period. The penetration depths are plotted separately for TE mode (left column of dots beneath each site) and TM mode (right column with gray bar in the background). (top) The depth range 0-40 km and (bottom) the range 0-400 km.

if the actual errors are lower). The phase differences between the orthogonal directions are, for many data, reasonably small $\left(<15^{\circ}\right.$ implies low order of multidimensionality). Phase tensor analysis [Caldwell et al., 2004] (not shown), and especially the small phase tensor skew angles found, confirm that
2-D modeling, inversion and interpretation of the profile are appropriate.

[12] The dominant geoelectric strike direction of $55^{\circ} \mathrm{E}$ of north is parallel to the direction of the terrane boundary between the Ghanzi-Chobe and Magondi mobile belts based

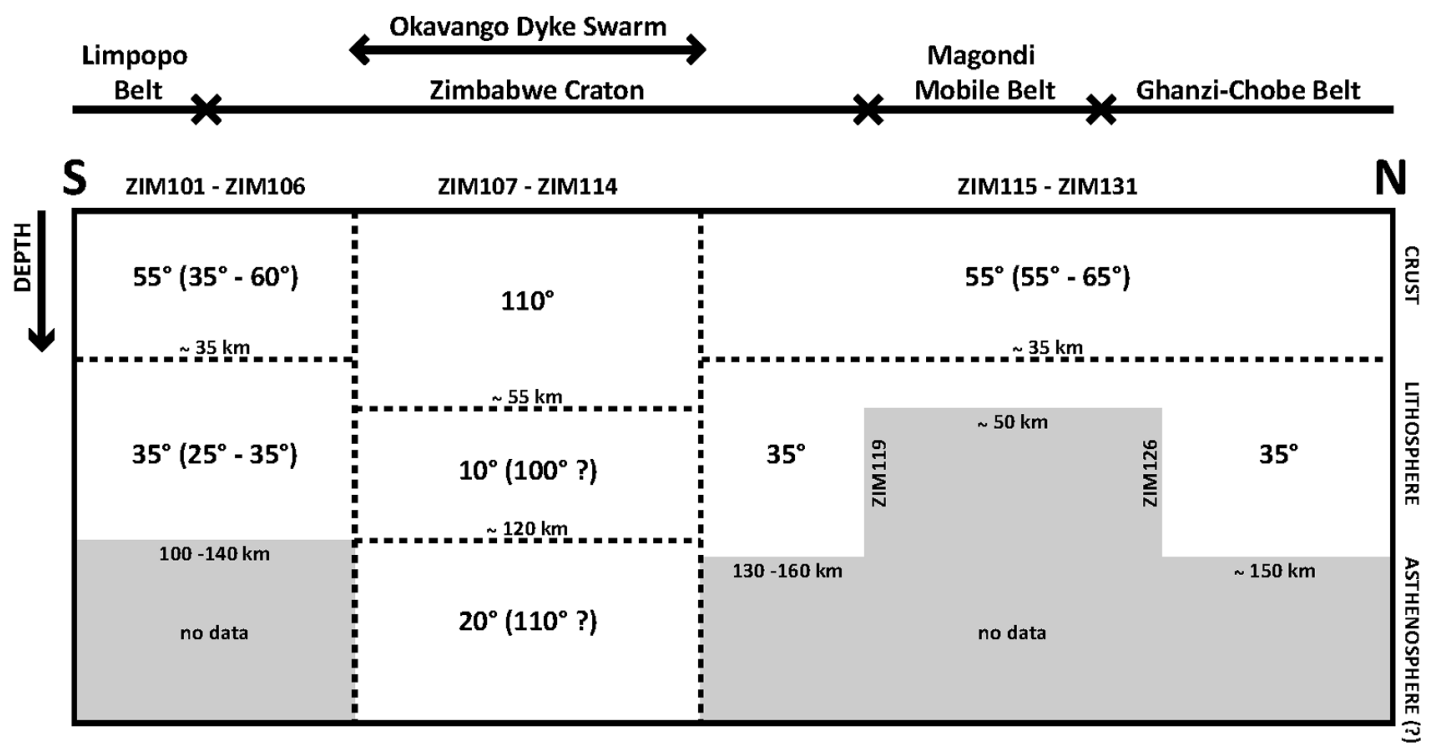

Figure 3. Sketch of the different strike angles for different depths and areas of the ZIM profile. The values in parentheses are the ranges of possible strike directions depending on the grouping of sites and frequencies, whereas the preceding angle is the one chosen as the final strike angle for that part of the profile. 

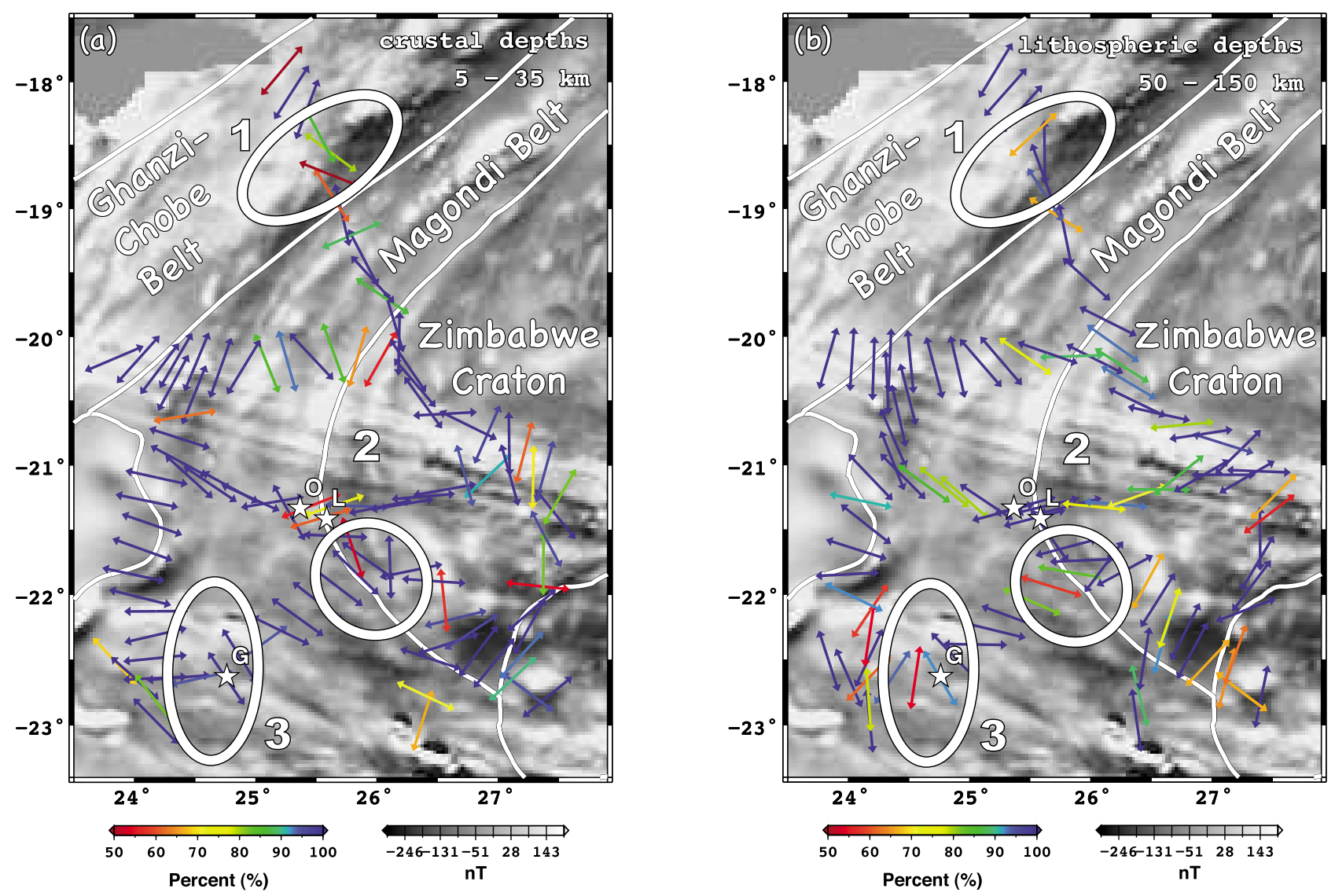

Figure 4. Most conductive directions (see explanation in text) over (a) crustal (5-35 km) and (b) lithospheric mantle $(50-150 \mathrm{~km})$ depth ranges. The color coding indicates the percentage of the frequencies in the depth range on which this direction is based for each individual site. Blue $(100 \%)$ means all frequencies in this depth range show the same most conductive direction whereas red $(50 \%)$ represents sites where the direction plotted is only based on half of the frequencies, while the other half is in favor of the perpendicular direction as most conductive. The numbered white ellipses indicate the $90^{\circ}$ flips in the most conductive direction discussed in the text. The regional magnetic map is shown as gray-scale background (magnetic data courtesy of the Council for Geoscience, Pretoria, South Africa), and the white lines indicated the suggested, regional-scale terrane boundaries based on the magnetic anomalies. The parallel, $110^{\circ} \mathrm{E}$ of north magnetic anomalies (between $20^{\circ}$ and $-21^{\circ}$ ) are associated with the Okavango dike swarm. The white stars indicate the locations of the Gope $(\mathrm{G})$, Letlhakane $(\mathrm{L})$, and Orapa $(\mathrm{O})$ kimberlite pipes.

on the SADC (Southern African Development Community) magnetic data set [Webb, 2009] (Figure 4). Therefore, this direction was chosen for separate inversion and interpretation of the northern crustal part of the ZIM line. For the whole data set, the geoelectric strike direction was taken to be $35^{\circ} \mathrm{E}$ of north. Firstly, because the major focus of the work lies in lithospheric structures and the depths to the electrical lithosphere-asthenosphere boundary, and secondly, because the data set has an approximately $20 \mathrm{~km}$ site spacing and is undersampled with respect to providing a detailed image of the crust. For the inversion of the whole data set, as well as for the northern crustal subset, a data set with a consistent strike direction is required for each. Therefore single-site, frequency-independent decompositions were performed on each MT site with a fixed strike angle of $55^{\circ} \mathrm{E}$ of north and $35^{\circ} \mathrm{E}$ of north, respectively, to derive the most accurate regional 2-D impedances and calculate the frequencyindependent twist and shear galvanic distortion parameters. Note, this decomposition technique is not the same as a simple rotation of the data into the prescribed strike directions [Jones and Groom, 1993; McNeice and Jones, 2001]. For the crustal data set, in addition to the decomposition, the NiblettBostick penetration depths were estimated for all data of both modes independently and all data points at periods with penetration depths greater than $40 \mathrm{~km}$ were excluded.

[13] The results of the decomposition and strike analyses themselves can provide valuable information about the location of boundaries and their depth extent, even before applying any modeling or inversion tools. As the geoelectric strike direction suffers from a $90^{\circ}$ ambiguity, to be consistent the most conductive direction is plotted (Figure 4). The most conductive direction may be subject to $90^{\circ}$ "flips" of the strike arrows at a fault or terrane boundary. As an illustrative example, consider a simple quarter space containing a fault between resistive and conductive blocks. On the resistive side the TE mode is more conductive (has lower apparent resistivity and higher phase) than the TM mode, whereas on the conductive side of the fault the TM mode is more conductive 
than the TE [see Hamilton et al., 2006, Figure 5]. Therefore, at a fault or a terrane boundary a $90^{\circ}$ flip in the most conductive direction will occur. The TE mode is defined as having the electric field parallel to the strike direction of the fault, so the most conductive direction on the resistive side will correspond to the direction of the TE mode electric field. Since the apparent resistivity values could be affected by static shifts, the definition of the most conductive direction of the true structure based on the apparent resistivity curves alone could be misleading. As the phases are unaffected by static shifts, which are the only effects that remain after Groom-Bailey distortion decomposition has been applied to data from a 2-D resistivity environment, it is preferred to use the maximum phase instead of the minimum resistivity to define the most conductive direction.

[14] Maximum phases are used to determine the most conductive directions plotted in Figure 4. Some of the $90^{\circ}$ flips in most conductive direction can be found in the crust (Figure 4a) as well as in the lithospheric mantle (Figure 4b). Since these directions represent a band of frequencies, phase crossovers within the band cannot be excluded, and therefore the color of the arrow at each site indicates the percentage of the frequencies in the band that show the plotted direction as the most conductive. A blue arrow $(100 \%)$ means all frequencies have a consistent most conductive direction, whereas red $(50 \%)$ indicates sites where half of the frequencies have a most conductive direction in the plotted orientation, but the other half is in favor of the perpendicular direction as the most conductive, i.e., that a phase crossover occurred at about the midpoint of the frequency band. Most of these undecided cases are located at places where a $90^{\circ}$ flip occurs, i.e., at or close to a boundary. Looking at the northern end of the ZIM line, the most conductive direction of the sites inside the Ghanzi-Chobe belt is approximately parallel to the proposed terrane boundary with the Magondi belt, whereas sites on the Magondi belt show a perpendicular most conductive direction. If the flip (highlighted as region 1 in Figure 4) is related to the terrane boundary between these two belts, two things can be concluded. First, the crust of the Magondi mobile belt is, overall, more conductive than that of the Ghanzi-Chobe mobile belt, and second, the previously specified terrane boundary between the two, defined on the basis of larger-scale geophysical responses, is drawn too far to the south since the flip happens somewhere around ZIM128 (and not ZIM124) at crustal as well as lithospheric depths. Although the terrane boundary defined on a far more regional basis using the SADC magnetic data is too far south, the local magnetic anomalies infer and support the upper crustal boundary being at $\sim$ ZIM128 as indicated by the most conductive directions.

[15] While no flip can be identified at the terrane boundary between the Zimbabwe craton and the Magondi mobile belt on the ZIM line, there are two $90^{\circ}$ flips in the most conductive direction in the southern part of the mapped area which could indicate the southwestern boundary of the Zimbabwe craton. One is located at the proposed boundary of the Zimbabwe craton, where the most conductive direction at the sites west of the flip (highlighted as region 2 in Figure 4) is oriented parallel to the outlined boundary and the sites east of it show directions perpendicular to it. If that is the correct terrane boundary for the craton, then the most conductive direction would suggest that the crust of the craton has a higher integrated conductivity (conductance) than the neighboring mobile belt, which would contrast with the response of many other mobile belts [see, e.g., Jones, 1981; Hyndman and Shearer, 1989]. The other location is a little further to the west-southwest (highlighted as region 3 in Figure 4). The sites to the west indicate being on the more conductive site, whereas the sites to the east show a most conductive direction that would place them on the more resistive side of the boundary. If the Zimbabwe craton extends westward that far (as far as flip 3), the sites on the east would be located on the craton and the shift in the terrane boundary would agree with the expectation of a resistive craton. Another supportive argument for the revised position of the boundary of the westernmost extent of the Zimbabwe craton is the fact that in Gope ("G" in Figures 1 and 4) diamondiferous kimberlites have been found (mining is supposed to start in 2012 [Read and Janse, 2009]), and diamondiferous kimberlites are known to appear preferentially on the edges of cratons [Griffin et al., 2004; Jones et al., 2009a]. Alternatively Gope may be located on the northern edge of the Kaapvaal craton as defined by Eglington and Armstrong [2004] (gray dashed line in Figure 1) and Corner [2008].

\subsection{Two-Dimensional Modeling}

[16] The decomposed, regional 2-D MT responses were imported into Geosystem's WinGLink interpretation software package that includes the latest 2-D modeling and inversion algorithm of Rodi and Mackie [2001]. The 2-D inversion code is a smooth model inversion routine that assumes isotropic resistivity cells in the mesh. It is based on a finite difference formulation to compute the regularized solution of the 2-D MT inverse problem. The inverse algorithm employs a nonlinear conjugate gradient scheme to minimize an objective function that penalizes data residuals and second spatial derivatives with respect to the resistivity structure [Rodi and Mackie, 2001].

[17] Where necessary a $D^{+}$consistency assessment [Parker, 1980; Parker and Whaler, 1981; Parker, 1982] was applied to the imported data to eliminate inconsistent data points before the inversion. All inversion results shown are based on the following settings (unless stated differently):

[18] 1. Seven decades of data with a minimum period of $0.001 \mathrm{~s}$ have been considered for the inversion.

[19] 2. It has been inverted for the observed station data.

[20] 3. If available, data errors have been used, otherwise the errors of the resistivity values were set to $10 \%$ and the errors in the phases to $5 \%$ (equivalent to $1.4^{\circ}$ ).

[21] 4. The error floors of the initial inversion run have been set to $5 \%$ for TM phase $\left(1.4^{\circ}\right), 25 \%$ for TE phase $\left(7.0^{\circ}\right)$ and $50 \%$ for the resistivities of both modes. Successively the error floors of the TE phase, of the TM resistivity and finally of the TE resistivity were reduced. The error floors of the final inversion run were 5\% for phases and $10 \%$ for apparent resistivity values.

[22] 5. Vertical magnetic transfer function data were not available for the ZIM line and therefore were not taken into account for inversion and interpretation.

[23] All of the start models were $100 \Omega m$ for the crustal data subset of the northern part of the profile and for the whole data set were $100 \Omega m$ for the top $\sim 400 \mathrm{~km}$, with a fixed bottom half-space of $10 \Omega m$ below (clamping parameter set to $10^{10}$; that is, the half-space resistivity was not permitted to vary). In 


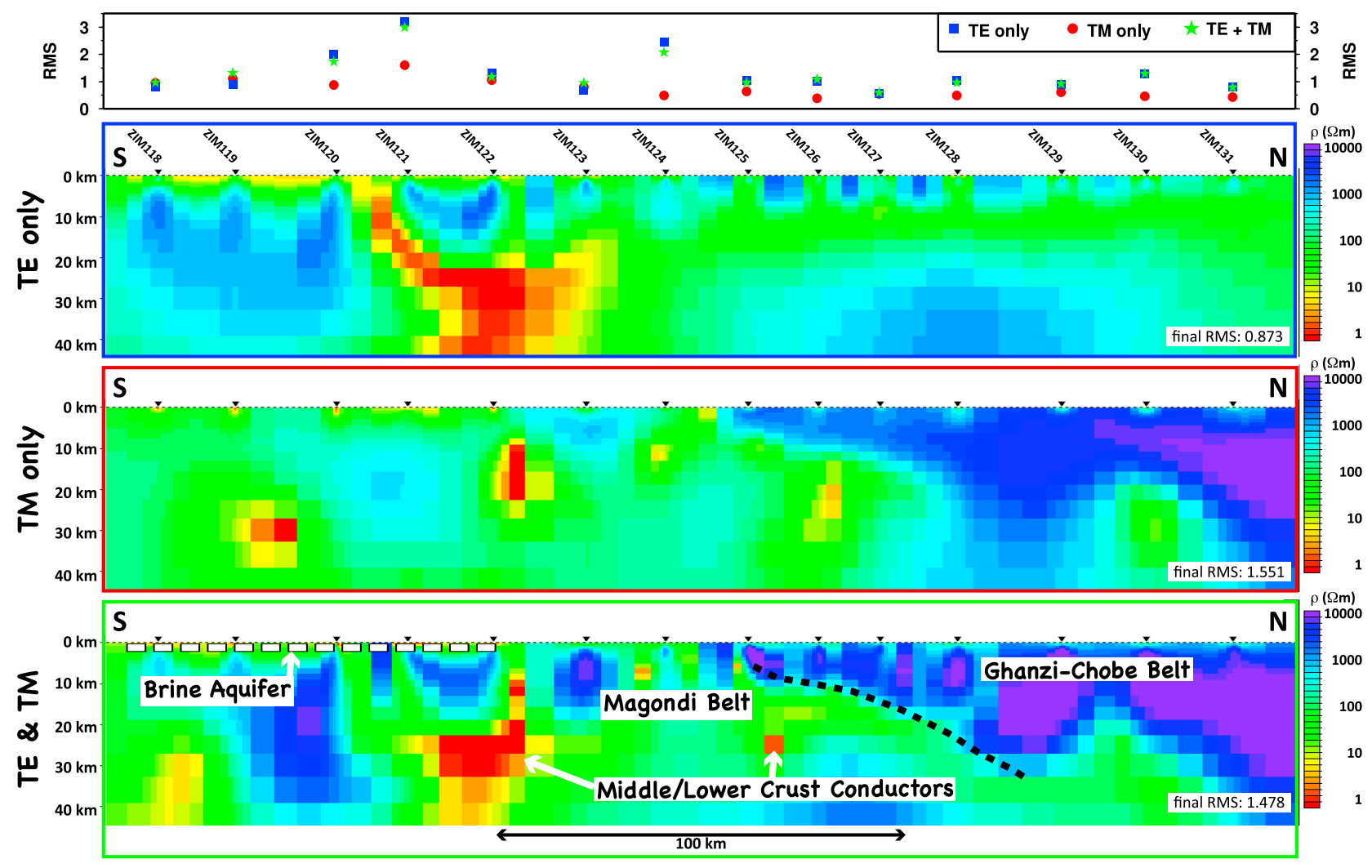

Figure 5. The inversion results of the crustal, northern part of the ZIM line (vertical exaggeration equals 1.0). (top) The result if only the TE mode data are used for the inversion. (middle) The result if only the TM mode data are taken into account during the inversion. (bottom) The result of a joint TE and TM mode data inversion. The RMS values of the TE, the TM, and joint TE/TM inversions at each individual site are shown at the top of the image. The geological interpretation of the model is sketched in Figure 5 (bottom). The black dashed line indicates the northward dipping boundary between the resistive Ghanzi-Chobe Belt to the north and the Magondi Belt to the south. Two major middle to lower crustal conductors are identified. The brine aquifer is indicated by the approximately $600 \mathrm{~m}$ thick conductive (about $1-5 \Omega \mathrm{m}$ ) layer beneath the southern sites (white dashed line).

the inversion, standard Laplacian regularization and minimizing the gradient of the model were used to calculated the models. The regularization parameter $\tau$ controls the trade-off between fitting the data and the model smoothness. A larger $\tau$ results in smoother models at the expense of higher RMS misfits. Therefore, initial inversion runs were necessary to determine the optimal regularization parameter for the chosen mesh and the data set (or subset). Since the resistivity data can be affected by static shifts, which would increase the RMS values, test runs were set up to fit the phases only. Trade-off curves for various weighting function parameters were analyzed and, based on these results, $\tau=6$ (for the whole data set with a strike angle of $35^{\circ} \mathrm{E}$ of north) and $\tau=1$ (for the crustal, northern part of the profile with a strike direction of $55^{\circ} \mathrm{E}$ of north) were chosen as the regularization parameters for the inversions. The weighting function parameters used were $\alpha=$ $1, \beta=0$ and $\mathrm{H} / \mathrm{V}=0 / 0$ for all inversions.

[24] A separate 2-D inversion of a data subset from the northern part of the ZIM profile was undertaken to investigate the crustal structures imaged when using the appropriate strike direction (i.e., $55^{\circ} \mathrm{E}$ of north). These results facilitate differentiation between true crustal structures and artificial structures in the inversion model of the whole profile caused by enforcing the lithospheric strike direction of $35^{\circ} \mathrm{E}$ of north to the crustal, northern part of the data. Besides the joint TE and TM mode inversion, inversions of the individual modes only, starting with inverting for phase only and then adding the resistivity values, were also undertaken. Figure 5 shows the inversion results of TE-only, TM-only and joint TE+TM inversions (different weighting function parameters were also tested but did not lead to any significant changes in the inversion results). The resistivity structures obtained from the TE-only (Figure 5, top), TM-only (Figure 5, middle) and joint TE+TM (Figure 5, bottom) inversions clearly exhibit differences, which is a well known issue [e.g., Unsworth et al., 1999; Ritter et al., 2003] that is caused by the different sensitivities of the two independent modes. Whereas the TM mode is primarily sensitive to electrical charges at boundaries, the anomalies in the TE mode are inductive in nature; that is, the TE mode is sensitive to the current flow [e.g., Jones, 1983b; Wannamaker et al., 1984; Berdichevsky et al., 1998]. Wannamaker et al. [1984] state that the apparent resistivity identified as TE by conventional means over and around a confined 3-D conductive body suffers a widespread depression (due to current gathering) that is increasingly pronounced toward longer periods. The interpretation of such 
a 3-D response using 1-D or 2-D TE modeling routines would infer erroneously low resistivities at depths below the true inhomogeneity [Wannamaker et al., 1984]. Such an effect is apparent in the TE mode inversion results in Figure 5 (top), which exhibits a middle to lower crustal conductor that extends clearly deeper than it does for the TM mode inversion (Figure 5, middle) or the joint TE+TM inversion (Figure 5, bottom). Berdichevsky et al. [1998] studied the advantages and disadvantages of the individual modes using synthetic data generated for different geological scenarios. They found the TM mode to be more sensitive to near-surface structures, whereas the TE mode is generally more sensitive to deeper structures, the exception to this being for strongly anisotropic conductors when the TE mode becomes "arrested" in the conductor whereas the conductor can be invisible to the TM mode [Jones, 2006]. Berdichevsky et al. [1998] also noticed that the TM mode is more accurate if a conductive 3-D structure is interpreted by a 2-D approximation (similar to the observations of Jones [1983b], Wannamaker et al. [1984] and Ledo et al. [2002]), whereas in the case of a resistive 3-D body, the TE mode may be more accurate. Therefore, the information that can be obtained from the individual TE and TM modes complement one another, and, as expected, the joint TE+TM inversion (Figure 5, bottom) exhibits some features from each of the inversions of the individual modes (Figure 5 (top) and Figure 5 (middle)).

[25] To test if some key structures are supported by the data, the joint TE+TM inversion model was manually edited (e.g., conductors or resistors were removed and tear zones were introduced, i.e., allowing for sharp boundaries at the edges of these zones) and used as starting models for new inversion sequences using the option to find the model closest to the starting model. All the inversion results of the different manually edited starting models suggest that the northward dipping base of the resistor, top of the more conducting lower crust, beneath sites ZIM125 to ZIM131 seen in the TM-only and TE+TM model is a data-supported structure, including the visible updoming at the base of the resistor beneath site ZIM130. With regard to the main conductors imaged, although the shape of the conductors beneath sites ZIM121 to ZIM123 and beneath site ZIM125 to ZIM126 varies from model to model, the existence of these conductors is a persistent feature that returns whatever the starting model or data subset (provided TM data are included in the case of the conductor below ZIM126). The two upper crustal resistors beneath sites ZIM121/ZIM122 and ZIM123 remain disconnected and the vertical resistive structure beneath ZIM119/ ZIM120 is a distinctive block with sharp boundaries in the resistivity model. Finally, a thin, near-surface conductor can be found beneath ZIM118 to ZIM122 which appears discontinuous due to the sparse lateral sampling provided by a site spacing of about $20 \mathrm{~km}$, but imposing the conductor in the model as a continuous feature is accepted by the inversion as well. The tests suggest that the inversion model shown in Figure 5 represents the data well.

[26] Figure 6 illustrates the preferred lithospheric-scale 2-D isotropic smooth inversion model for the whole ZIM line. (During the inversion process the data from sites ZIM102, ZIM103, ZIM104, ZIM107, ZIM113 and ZIM115 were excluded as they could not be fitwell by the model responses and their individual site RMS values were greater than 15.) For each site the individual TE-only (stars), TM- only (squares) and joint TE+TM (red circles) RMS values are plotted above the model, clearly showing that for nearly all sites it is more difficult to fit the TE mode data than the TM mode data. It is also apparent that the data of the northern sites are better fit than the data of the southern sites. In addition to the quality of data fit, the model constraints depend also on the data distribution with respect to the 2-D section. As discussed above, the penetration depth varies not only from site to site but also between the two modes, as shown in Figure 6 . Unfortunately, the region of the upper mantle between the two deeper resistors in the south (resistive feature R4 in Figure 6) and north (R5) of the profile is not sensed by the sites above it, but only by those sites to the side, and therefore raises the question whether R4 and R5 are connected or not. A further interesting question is whether the upper resistors (R1, $\mathrm{R} 2$ and R3) in the crust and the lower resistors (R4 and R5) in the lithospheric mantle are connected or not, and if the connection that is apparent beneath ZIM131 between R3 and $\mathrm{R} 5$ is real or an artifact of the smooth inversion regularization. The existence of the two conductors beneath ZIM121-123 and ZIM125 are not questioned as they conform with the conductors found in the focused inversion of the northern crustal part of the profile; see Figure 5.

[27] To test the requirement for the presence of the (relatively more) conductive zone between resistive features R4 and R5 laterally in the mantle, and the crustal resistive features (R1, R2 and R3) and the upper mantle ones (R4 and R5) vertically, the final 2-D inversion model was manipulated by forming resistive connections between them. Different manipulated models were designed, for which forward responses were calculated and compared to the observed data and the responses of the final 2-D inversion model in Figure 6. The comparisons demonstrated that the lack of vertical connectivity of the different resistors in the final inversion model is constrained by, and consistent with, the observed data, consistent with an electrical decoupling of the crust and mantle. (Note, that sites ZIM101 and ZIM105 are only poorly fitted and that sites ZIM102-ZIM104 were rejected as they could not be fitted at all. Therefore, the area of the ostensible coupling of resistor R4 to the crust is a poorly resolved structure in the model.) However, in the area of very limited penetration depth beneath sites ZIM118 to ZIM123, the data do not provide any constraints on the lateral connectivity of the mantle resistors in the south (R4) and north (R5).

\section{Interpretation and Discussion}

\subsection{Crustal Model}

[28] The relevant constraints for the interpretation of the crust in the northern part of the profile, based on known geology, results from previous geophysical investigations and the most conductive direction maps of the ZIM line area, are summarized in cartoon form in Figure 7. The Makgadikgadi pans are associated with a near-surface brine aquifer causing a near-surface layer of low resistivity. The possible extent of the brine aquifer with respect to the ZIM site locations is indicated by the orange line (Figure 7a). The black horizontal arrows outline the inferred locations of the crustal conductor mapped by de Beer et al. [1975, 1976, 1982] and van Zijl and de Beer [1983] using electrical sounding and magnetometer array data. This crustal conductor extends from Namibia, through northern Botswana into Zimbabwe 

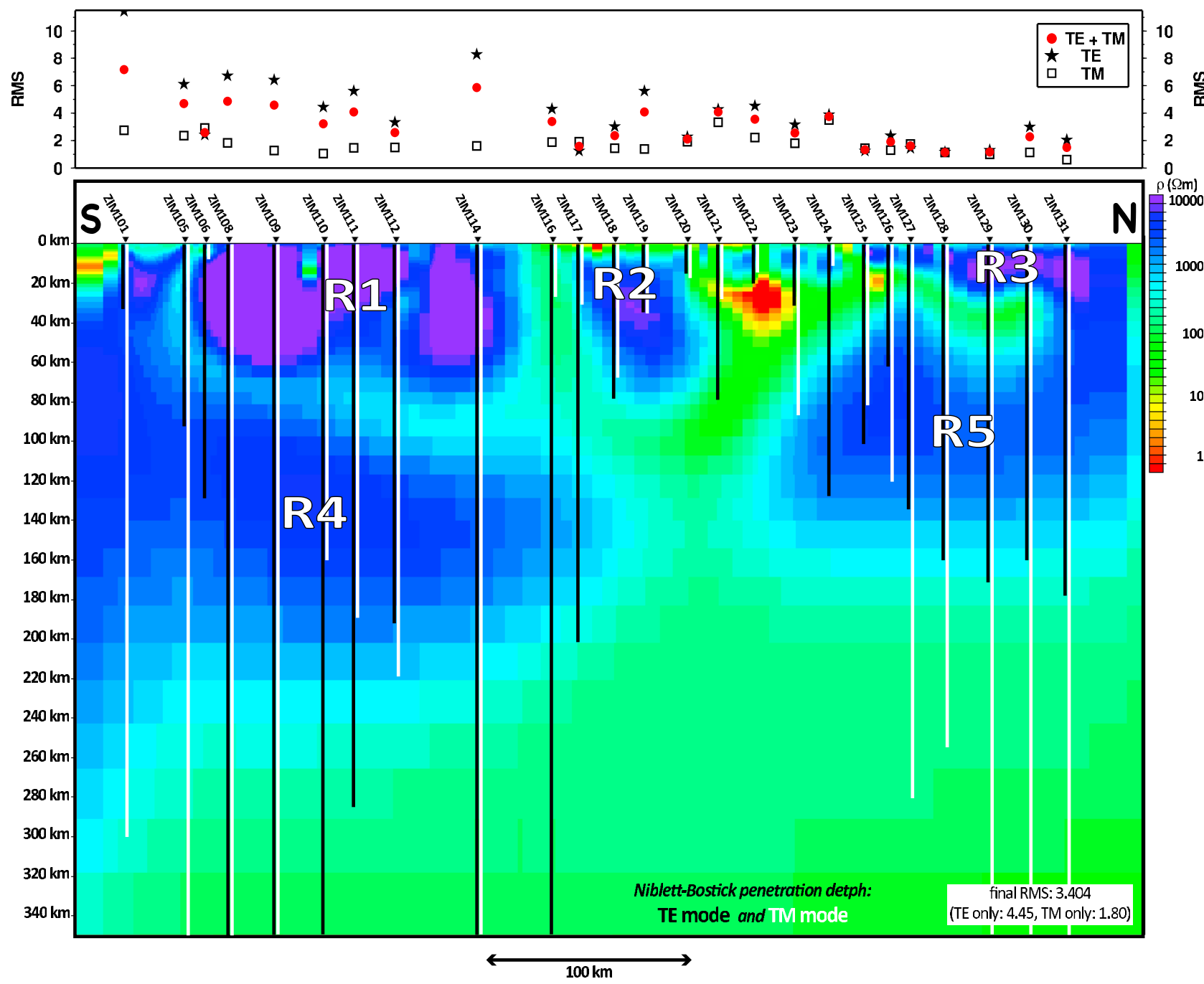

Figure 6. Final 2-D smooth inversion model of the ZIM line (vertical exaggeration equals 1.0). The triangles indicate the locations of the sites used, and the black and white lines beneath each site represent the Niblett-Bostick penetration depths of the TE (black) and TM (white) mode data. The RMS values of the TE, the TM, and joint TE/TM modes with respect to the final model at each individual site is shown at the top.

and Zambia. Originally the conductor was thought to be an upper lithospheric mantle feature [de Beer et al., 1975, 1976], but de Beer et al. [1982] and van Zijl and de Beer [1983] revised the depth extent to be within middle to lower crust at depths $(20-45 \mathrm{~km})$. The locations of the boundary between the Magondi Belt and the Ghanzi-Chobe Zone, as proposed on the geological map of Singletary et al. [2003], is sketched in red, whereas the blue geological terrane outline is based on the SADC aeromagnetic data [Webb, 2009]. Finally, the transition in the most conductive strike direction, which indicates a resistor at the northern end of the profile (as discussed earlier), is represented in green. As the flip in the most conductive direction is a rather smooth transition (where not all frequencies in the crustal depth band agree in terms of the most conductive direction) rather than an abrupt change from one site to the next, an increasing thickness of the resistor toward the north, and therefore a dipping interface, could be anticipated. Figure $7 \mathrm{~b}$ shows a cartoon sketch of the probable resistivity structure based on the information prior to the modeling and inversion (i.e., from previous studies but also from the analysis of the most conductive directions) shown in Figure 7a. The Ghanzi-Chobe belt is expected to be a resistive feature, and the boundary with the Magondi Belt is most likely dipping northward with increasing thickness of the Ghanzi-Chobe belt from ZIM124/ZIM125 to about ZIM128/ ZIM129. The brine aquifer causes a thin near-surface conductor beneath sites ZIM118 to ZIM120 (perhaps as far as ZIM121/ZIM122) and there is possibly a boundary between the Zimbabwe craton and the Magondi Belt somewhere between ZIM119 and ZIM120. Finally, there are (one or possibly several) middle to lower crustal conductors likely; the exact locations in lateral position of which are unclear.

[29] Comparing the sketch of the possible subsurface resistivity structure with the 2-D inversion result for the MT data of the crustal northern part of the ZIM line (see Figure 5, bottom), shows good agreement. The northward dipping highly resistive structure is identified as the Ghanzi-Chobe belt, with the Magondi Belt to its south. A clear boundary 

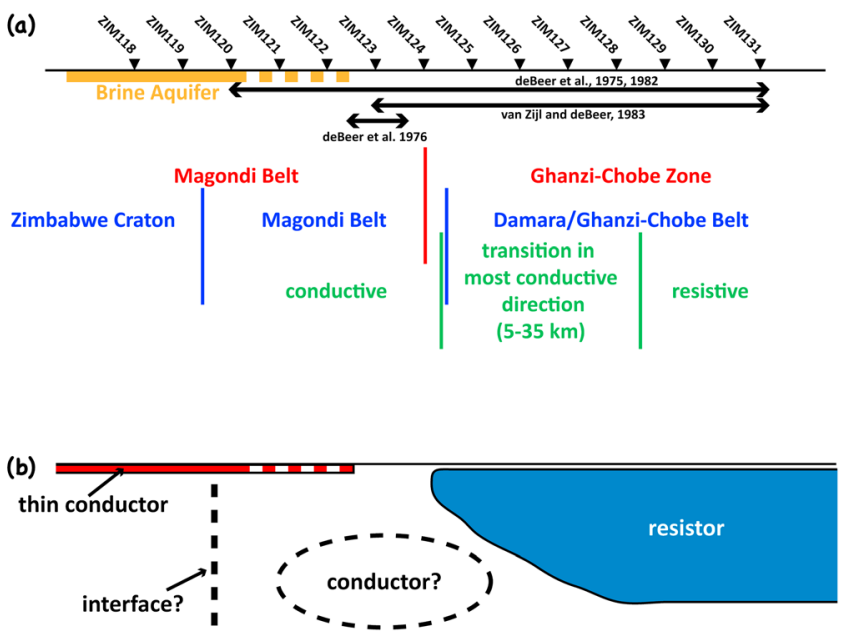

Figure 7. Sketch showing (a) the a priori information, i.e., from previous studies but also from the analysis of the most conductive directions, and (b) a possible subsurface resistivity structure based on them. In orange is the possible extent of the brine aquifer, which is related to the Makgadikgadi salt pan complex. The black arrows indicate the location of the crustal conductor (20-45 km depth) mapped by de Beer et al. [1975, 1976, 1982] and van Zijl and de Beer [1983] using electrical sounding and magnetometer array data. The location of the geological terranes as they are proposed on the geological map [Singletary et al., 2003, and references therein] are indicated in red, and that based on the aeromagnetic data are indicated in blue. In green is shown the zone of transition in the most conductive strike direction, which indicates a dipping resistor at the northern end of the profile (see Figure 4).

between the Magondi Belt and the Zimbabwe craton cannot be identified in the model. The thin (about $600 \mathrm{~m}$ thick) conductive (about 1-5 $\Omega m$ ) near-surface layer is related to the brine aquifer, and the two middle to lower crustal conductors have been found in the lateral range suggested by de Beer et al. [1975, 1976] and van Zijl and de Beer [1983]. The depth of the conductor beneath sites ZIM121/122 in the 2-D inversion model (see Figure 5, bottom) matches the depth range of 20-45 km proposed by de Beer et al. [1982] and van Zijl and de Beer [1983] for their conductor. They associated the conductor with a zone of crustal weakness and a serpentinized lower crust. Ritter et al. [2003] studied a conductive zone in the Damara Mobile Belt using MT data from a profile in western Namibia. These authors argued that improved knowledge and theory about crustal conductivity suggests that shear zones are a more plausible explanation, as they often have anomalous conductivity due to higher content of (saline) fluid, high permeability due to fault gouge, and the presence of sulphides and/or graphite. In the case of the ZIM line, no additional information about the presence of fluids, sulphides or graphites is available, but if de Beer et al. [1975, 1976, 1982] and van Zijl and de Beer [1983] are correct in their lateral mapping of the conductor, then the conductor investigated by Ritter et al. [2003] and the one found in the ZIM data are correlative. If that is the case, it seems reasonable to follow the arguments of Ritter et al. [2003] about the origin of the conductor: as graphite-bearing marble units are known to be present in the area, these units may account for the observed high conductivities and, although no supporting field evidence for hydrothermal alteration is available, fluids as a cause of the conductive anomaly cannot be ruled out. Laboratory measurements show that interconnected graphite flakes or graphite grain boundary coatings can significantly enhance electrical conductivity [e.g., Nover et al., 1998]. Ritter et al. [2003] suggest that regardless of what the conductive material in the rocks is, it must be reasonably well interconnected over a distance of kilometers to cause the observed anomalies, and that interconnectivity is best accomplished by movement along discrete fault zones. Sulphides must also be considered as a possible cause as base metal sulphide ores are known in the Damara Belt [e.g., Kamona et al., 1999; Chetty and Frimmel, 2000]. The introduction of sulphides into the deep crust during Pan-African Orogenesis is possible, in a similar fashion to the processes of closure of the Manikewan Ocean during the Paleoproterozoic Trans-Hudson Orogenesis that created the North American Central Plains (NACP) conductivity anomaly [Jones et al., 1993, 2005b], the longest conductivity anomaly known to date [Jones, 1993]. Laboratory studies showed that in the case of the NACP the pyrite grains had mobilized during subduction such that they are connected along strike and disconnected across strike [Jones et al., 1997], leading to very high electrical anisotropies even at the hand sample scale. In summary, the origin of the lower crustal conductor found in the ZIM data remains uncertain, but a graphite and/or sulphide origin is favored. It is also uncertain if the conductor mapped by de Beer et al. [1975, 1976, 1982] and van Zijl and de Beer [1983] is one continuous conductor extending from the Damara belt in Namibia [Ritter et al., 2003] to the Magondi belt in eastern Botswana (this study). If the conductor is continuous it would imply that it crosses the terrane boundary between the Magondi Belt and the Damara/ Ghanzi-Chobe belt. Therefore it would be younger than the age of accumulation of Damara/Ghanzi-Chobe sediments north of the Magondi belt and would require a largescale tectonic event, such as, e.g., shearing related to the Pan-African deformation and metamorphism. In contrast, Treloar [1988] and Treloar and Kramers [1989] state that the deformation and metamorphism found in the Magondi are of Paleoproterozoic to Mesoproterozoic age and that the Magondi belt is essentially unaffected by Pan-Africa tectonics. As Treloar [1988] and Treloar and Kramers [1989] investigated the Magondi belt in northeastern Zimbabwe (i.e., several hundreds of kilometers away) it cannot be excluded that parts of the Magondi belt in northeastern Botswana possibly have been affected by Pan-African deformation and metamorphism. On the other hand, it is also possible that the conductor is not continuous. The early magnetometer array and resistivity sounding studies [de Beer et al., 1975, 1976, 1982; van Zijl and de Beer, 1983] provide only a very sparse sampling of the locations of an observed conductor. At that time there was no knowledge of the terrane boundaries in this part of southern Africa, therefore interpreting the observed lower crustal conductors as one continuous conductor was reasonable. The more recent sampling of the lower crustal conductor with MT [Ritter et al., 2003; Muller et al., 2009] (also this study and additional SAMTEX profiles) is also too sparse to support or exclude a continuous conductor; it is possible that the conductor observed in the 


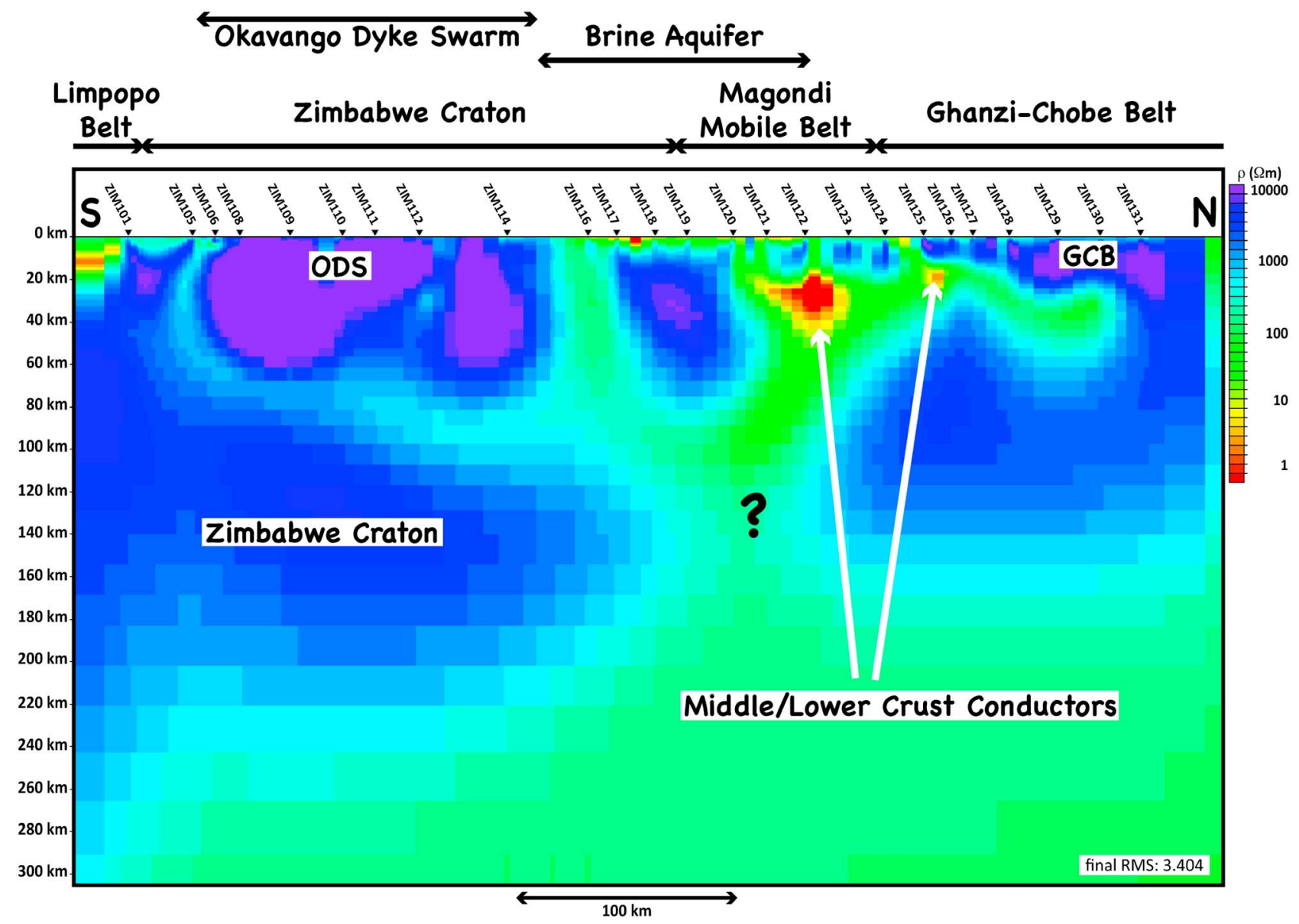

Figure 8. The 2-D smooth inversion model (vertical exaggeration equals 1.0) from Figure 6 in relation to the known surface extent of geological terranes. The arrows above the image of the resistivity structure show the crustal extents of the Limpopo Belt, Zimbabwe craton, Magondi Mobile Belt, and Ghanzi-Chobe Belt (GCB) with respect to MT sites of the ZIM line, adapted from the regional-scale geological terrane boundaries based on potential field data [Webb, 2009]. The extent of the Okavango Dike Swarm (ODS), known from magnetic data, is indicated, as well as an estimated extent of the brine aquifer related to the Makgadikgadi salt pan complex. The dominant resistivity features related to the main geological terranes are labeled, and the question mark indicates the area of missing data coverage. Two dominant middle to lower crustal conductors are also apparent (compare with inversion results from the northern crustal part of the profile (Figure 5)).

Magondi is not the same as that found in the Damara belt further west.

\subsection{Lithospheric Model}

[30] Figure 8 shows the 2-D resistivity model of the ZIM profile with respect to the known or postulated surface extent of the geological terranes, the magnetic anomaly due the Okavango Dike Swarm and the estimated extent of the brine aquifer related to the Makgadikgadi salt pan complex. Despite the different decomposition azimuths used, the crustal structures at the northern end of the "lithospheric" model (Figure 8) are very similar to those in the "crustal" model (Figure 5, bottom). Therefore, enforcing the lithospheric strike direction of $35^{\circ} \mathrm{E}$ of north for the whole data set has not introduced any spurious artifacts in the resistivity structure of the crust in the northern part of the profile. The middle to lower crustal conductors, and the dipping crustal resistor of the Ghanzi-Chobe Belt (GCB) (in Figure 8), remain dominant crustal features in the model of the whole ZIM profile. Another dominant crustal feature is the extremely high resistivity area that has a lateral extent that matches the location of the Okavango Dike Swarm (ODS) (in Figure 8).

[31] Most parts of the lithospheric mantle are resistive, but its thickness and resistivity vary along the profile. The Zimbabwe craton (on the southern end of the profile) is characterized by very thick and very resistive lithosphere, whereas the lithosphere beneath the Ghanzi-Chobe Belt is significantly thinner and less resistive. The more conductive part of the lithospheric mantle, beneath the Magondi Mobile Belt (sites ZIM117 to ZIM123), is unfortunately located in an area of poor data coverage (see above).

[32] Figure 9 shows a comparison of the geological map by Singletary et al. [2003] (Figure 9, left), the SADC regional magnetic field anomaly map (Figure 9, middle) and the Bouguer gravity map (Figure 9, right) with the resistivities of the 2-D inversion model for three different depth ranges. 
Geology map (Singletary et al., 2003)
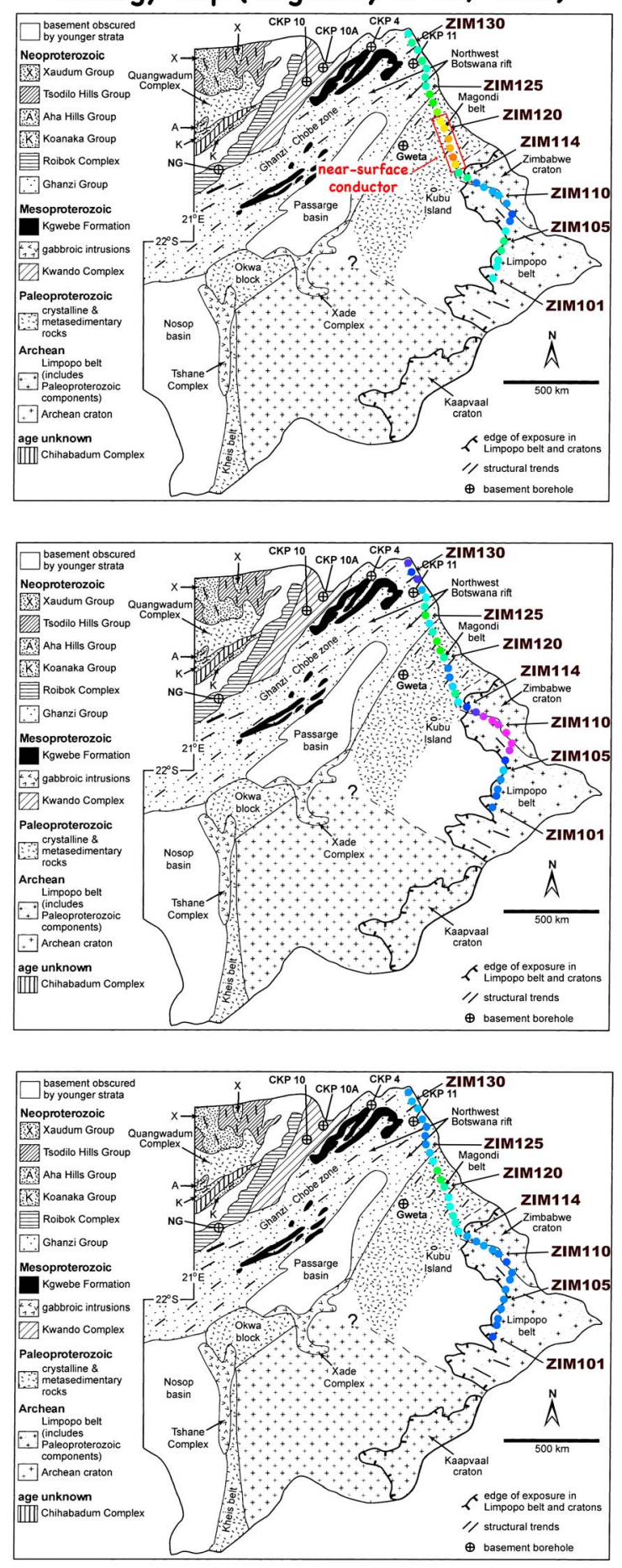
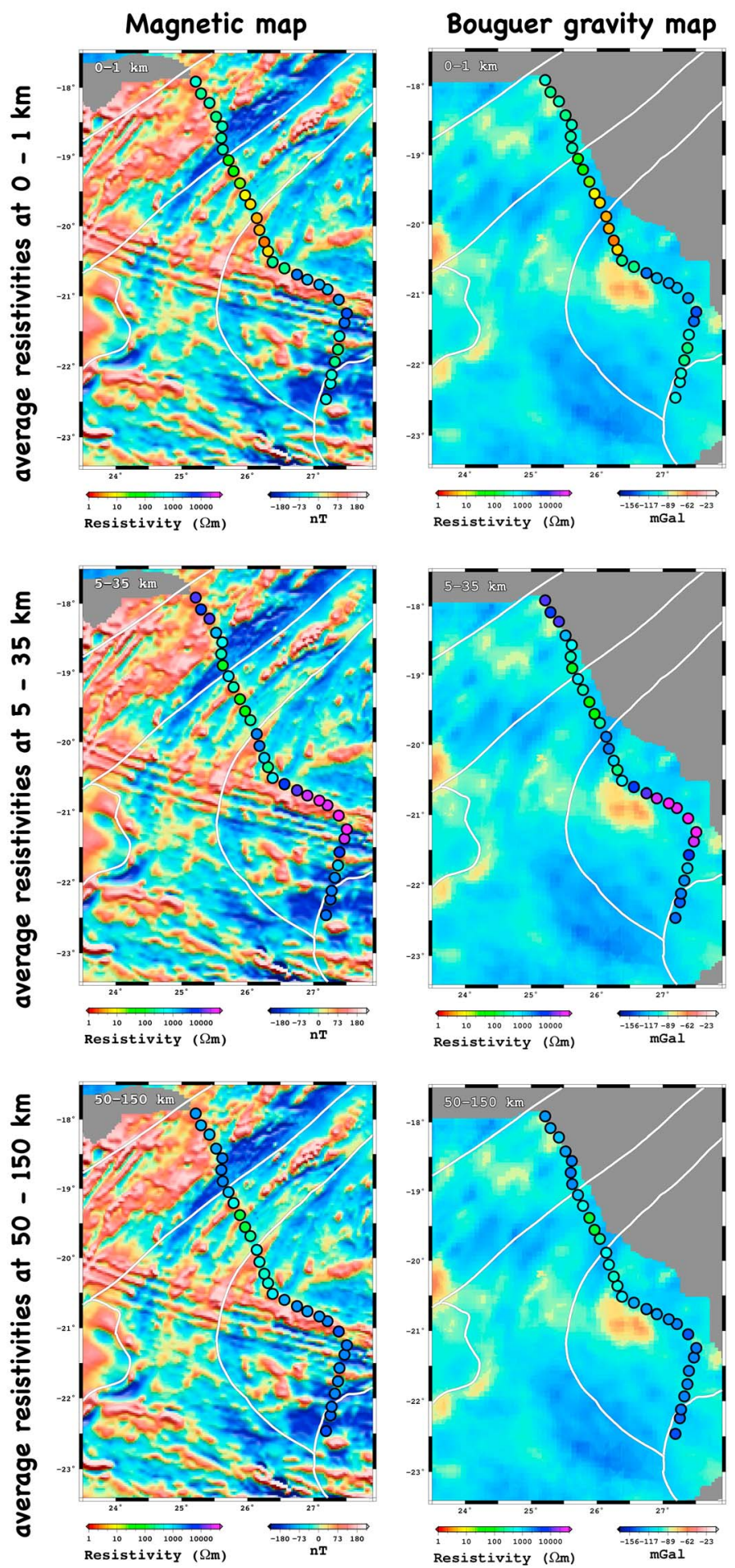

Figure 9. Average resistivity values of the 2-D inversion model (colored circles) beneath each site of the ZIM line for three different depth ranges, namely $0-1 \mathrm{~km}, 5-35 \mathrm{~km}$, and 50-150 km. (left) Background map is the subsurface Precambrian geology map (reprinted from Singletary et al. [2003], with permission from Elsevier), (middle) the regional magnetic anomaly map, and (right) the Bouguer gravity map (magnetic and gravity data courtesy of the Council for Geoscience, Pretoria, South Africa). Note the color scale of the circles indicating the resistivity values at each site is the same for all panels. 
The average resistivity values (calculated as the mean of the logarithmic resistivity values) beneath each ZIM site were extracted from the 2-D inversion model for three depth ranges: near-surface $(0-1 \mathrm{~km})$, crustal depths $(5-35 \mathrm{~km})$ and lithospheric depths $(50-150 \mathrm{~km})$. The near-surface resistivities exhibit the conductor that is associated with the brine aquifer of the Makgadikgadi pan complex; the conductor is spatially located in the Gweta and Kubu Island area on the geological map (Figure 9, top left). No correlation between the magnetic anomaly map and the near-surface resistivities is apparent (Figure 9, top middle). At crustal depths (5$35 \mathrm{~km}$ ), the high resistivities found at the southern end of the ZIM line fall into the Archean Zimbabwe craton and the Limpopo Belt on the geological map (Figure 9, middle left), whereas the extremely resistive part (purple color) matches the magnetic anomaly of the Okavango dike swarm (middle magnetic map). The resistive northern end is located in the Ghanzi-Chobe Belt (Figure 9, middle left), but not all sites in the belt at crustal depths are highly resistive. At lithospheric mantle depths $(50-150 \mathrm{~km})$ the resistive northern and southern ends of the profile correlate with the Ghanzi-Chobe Belt and the Zimbabwe craton (and Limpopo Belt), respectively (Figure 9, bottom left). The more conductive zone (green) matches the lateral extent of the Magondi Mobile Belt (although, the resistivity values are not well constrained due to the lack of penetration depth in that area). No correlation between the magnetic anomalies and the resistivity structure at lithospheric depths can be found (bottom middle), which is not surprising as the magnetics are sampling shallower targets at temperatures below the Curie isotherm. Comparing the resistivity values with the Bouguer gravity map, no correlation can be identified for these two data sets.

[33] The thickness of the resistive lithosphere can reliably be estimated as the MT method is sensitive to the top of the underlying, relatively more conductive layer (i.e., in this case the asthenosphere) [Jones, 1999]. Curves of average (i.e., mean logarithmic) and maximum resistivity versus depth for each terrane (shown in Figure 10c), calculated within areas defined in Figures 10a and 10b, illustrate differences in the bulk or average resistivity characteristics for each terrane traversed on the ZIM and the KIM-NAM profiles. Muller et al. [2009] published two independent inversion models of the KIM-NAM profile traversing the Damara and GhanziChobe belts, the Rehoboth Terrane and the Kaapvaal craton (see blue circles in Figure 1 for site locations), one for a $25^{\circ} \mathrm{E}$ of north strike angle for the Rehoboth Terrane, and one for $45^{\circ} \mathrm{E}$ of north for all the other terranes (Figure 10a shows a composite of these two), and determined the lithospheric thicknesses of the Kaapvaal craton (Eastern Block $220 \mathrm{~km}$, KBE, Western Block $190 \mathrm{~km}, \mathrm{KBW})$, the Rehoboth Terrane $(\sim 180 \mathrm{~km}, \mathrm{RBT})$ and the Damara/Ghanzi-Chobe Belt ( $\sim 160 \mathrm{~km}, \mathrm{DMB})$ using the resistivity versus depth profiles shown in gray in Figure 10c and constraints from xenolith data. For comparison, the resistivity-depth curves of the three ZIM line terranes (defined in Figure 10b), namely Zimbabwe craton (ZIM), Magondi Mobile Belt (MMB) and GhanziChobe Belt (GCB), are plotted as colored curves. (Note that the resistivity curve of the Magondi Mobile Belt is unconstrained below $\sim 80-100 \mathrm{~km}$ due to the limited penetration depth in that area.) None of the three ZIM line resistivity curves match any of the KIM-NAM resistivity-depth profiles. Unfortunately, the KIM-NAM and ZIM profiles do not intersect, therefore a static shift of absolute resistivity values between the two models cannot be excluded. However, the average resistivities for the ZIM line terranes show clear relative differences between one another, e.g., at about $150 \mathrm{~km}$ depth the Zimbabwe craton is, at $\sim 3000 \Omega m$, nearly 1 order of magnitude more resistive than the Ghanzi-Chobe Belt which has an average resistivity of $\sim 500 \Omega \mathrm{m}$. An increase in temperature results in a decay in electrical resistivity of mantel minerals [Constable et al., 1992; Xu and Shankland, 1999; Xu et al., 2000; Jones et al., 2009b]. Therefore, the bulk resistivity is lower if the geotherm is hotter, which is associated with a thinner lithospheric thickness (see Figure 10c where hypothetical mantle geotherms for several different lithospheric thicknesses are shown). Assuming a uniform grain size and the absence of graphite, sulphide and hydrogen, compositional variation in the mantle has only a minor influence on the electrical resistivity compared to the temperature effects [Maumus et al., 2005; Jones et al., 2009a, 2009b]. Therefore, the lithospheric geotherm (i.e., the temperature of the lithosphere) is a more plausible explanation for the observed variation in the bulk resistivities of the different terranes.

[34] On both the KIM-NAM and the ZIM profile, the cratons, namely the Eastern Kimberley Block of the Kaapvaal craton and the Zimbabwe craton, are associated with the coolest geotherm and therefore the thickest lithosphere. Hotter geotherms (and thinner lithosphere) are associated with the mobile belts, i.e., GCB, MMB (no constraints below $80-100 \mathrm{~km}$ ) and DMB. For a dry cratonic lithosphere, very high resistivities are predicted in the upper mantle (above $120 \mathrm{~km}$ ) but all resistivity-depth profiles in Figure 10c fail to match these values. A number of different reasons may be considered as explanation. First, the MT method is much less sensitive to the absolute resistivity of a resistive layer than to its thickness. If the resistive layer is located below a more conductive layer such as the crust, then the inaccuracy of the absolute resistivity estimation is enhanced [see, e.g., Jones 1999]. Second, smoothing has been applied due to the regularization used by the 2-D smooth inversion algorithm and also averaging was used to compute the resistivity-depth profiles themselves (although the variance, which is affected by the regularization, at lithospheric depths is very small). Furthermore, it is known that for example the presence of hydrogen in the mantle [Karato, 1990, 2006], partial melts or very small grain sizes in shear zones [ten Grotenhuis et al., 2004] also enhance the conductivities but these effects are neglected in the purely temperature-based model predicting the high resistivities in the upper mantle. One can though exclude hydrogen diffusion in cratonic mantle, as the amount of water in olivine in these settings is generally far too low [Gose et al., 2008], by a factor of four or more, than needed to account for the reduced resistivities. At depths shallower than $\sim 120 \mathrm{~km}$ (temperatures cooler than $\sim 1000^{\circ} \mathrm{C}$ ) hydrogen diffusion is also very inefficient and does not affect the bulk resistivity significantly. A grain size related enhancement of conductivities cannot be exclude for the relative more conductive lithospheric mantle beneath the Magondi belt. Although the data coverage is poor in this area, it could nevertheless represent a real structure similar to that found by Spratt et al. [2009] in the upper Wopmay lithospheric mantle in the Northwest Territories, northern Canada. Spratt et al. [2009] find very high resistivities down to about $210 \mathrm{~km}$ 

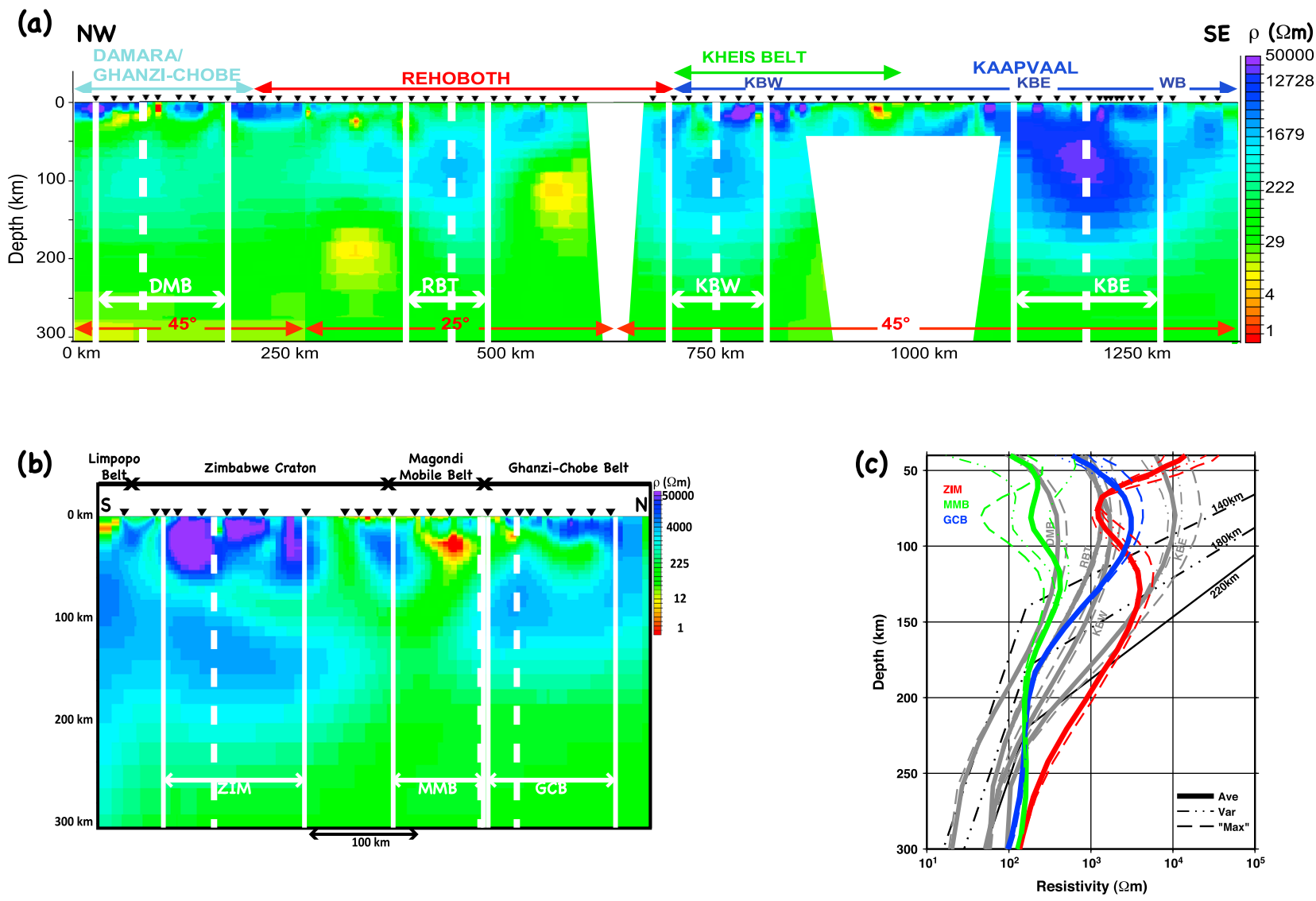

Figure 10. Electrical resistivity models for (a) the profile KIM-NAM [after Muller et al., 2009] and (b) the ZIM line using the same resistivity color scale as for the KIM-NAM profile in Figure 10a. (c) Representative resistivity-depth profiles for the different geological terranes are shown. In Figure 10a the profile is a composite of the two independent inversion runs for a $25^{\circ} \mathrm{E}$ of north strike angle for the Rehoboth Terrane and $45^{\circ} \mathrm{E}$ of north for all other terranes, with the surface extent of the geological terranes shown above and the solid vertical white lines define the zones used in each terrane to compute the average resistivity profiles presented in Figure 10c. The dashed white lines indicate the position of the "maximum" resistivity profiles in Figure 10c. Analogous, the white solid and dashed lines in Figure 10b define the zones used to compute the average resistivity profiles and the position of the maximum resistivity profiles for the three terranes traversed by the ZIM profile. In Figure 10c profiles of average resistivity, variance, and maximum resistivity are shown as indicated by the key. The profiles published by Muller et al. [2009] are shown in gray and are overlain by the colored ones from the ZIM model in Figure 10b. The average (and variance) profiles are computed from the 2-D sections within the spatial areas defined in Figures 10a and 10b. Predicted resistivity-depth profiles for hypothetical mantle geotherms for different lithosphere thicknesses are shown (black dash-dotted and dashed lines), based on laboratory electrical conductivity versus temperature and pressure measurements for dry olivine and pyroxene [Constable et al., 1992; Xu and Shankland, 1999; Xu et al., 2000]. The inflection point in the theoretical curves corresponds with the intersection of the conductive mantle geotherm with the adiabat. Abbreviations used are as follows: Damara/Ghanzi-Chobe (DMB) (for the KIM-NAM line), Rehoboth (RBT), Western Kimberley Block (KBW), Eastern Kimberley Block (KBE), Zimbabwe craton (ZIM), Magondi (MMB) (profile unconstrained below 80-100 km due to limited penetration depth in this area), and Ghanzi-Chobe (GCB) (for ZIM line).

depth that shoal to about $150 \mathrm{~km}$ depth beneath the western edge of the Archean Slave craton, similar to the southern part of the ZIM profile where the southwestern edge of the Zimbabwe craton is imaged. At depths of about $100 \mathrm{~km}$ in the Northwest Territories data there is a distinct decrease in the overall resistivity located between the Great Bear magmatic zone and the Phanerozoic platform compared to the neighboring resistive mantle [Spratt et al., 2009]. Such a lower-resistivity lithospheric mantle might be apparent beneath the Magondi Mobile Belt surrounded by the resistive Archean Zimbabwe craton and the Mesoproterozoic to Neoproterozoic Ghanzi-Chobe Belt. Interpretation of moderately resistive (some hundreds of $\Omega m$ ) mantle is fraught with difficulty; none of the currently proposed mechanisms for reducing resistivity in cratonic lithosphere is without serious objection. In the case of the Wopmay lithospheric mantle, Spratt et al. [2009] suggest an explanation predicting that upper mantle shear zones have a 1.5-2 orders of mag- 
nitude higher conductivity than less deformed regions in the lithosphere, based on work by ten Grotenhuis et al. [2004]. ten Grotenhuis et al. [2004] found a systematic, inverse linear relationship between the electrical conductivity of mantle olivine and its grain size on a micrometer scale. Whereas a change of size for grains larger $1 \mathrm{~cm}$ has no effect on the electrical conductivity, for grains smaller than $1 \mathrm{~cm}$ a significant increase in grain size is predicted to lower the conductivity by up to two orders of magnitude due to reducing grain boundary effects. Assuming a stable mantle grain size of $>1 \mathrm{~cm}$ [Spratt et al., 2009, and references therein] a reduction of grain size to $100 \mu \mathrm{m}$ would be required to obtain the resistivity changes of the order found beneath the Wopmay orogen [Spratt et al., 2009] and also beneath the Magondi belt, possibly suggesting the presence of a mantle shear zone in the Magondi belt. (Note, that such an explanation might also be possible for the conductive lithospheric mantle at the well imaged boundaries of the Rehoboth Terrane presented by Muller et al. [2009].) Considering largescale shearing as a possible cause of the continuous crustal conductor from Namibia to northeastern Botswana (see section 4.1), the lithospheric mantle could also have been subject to the same or similar stresses and could have undergone deformation at a comparable lateral scale. Such a tectonic scenario, with mantle shearing and associated reduction in mineral grain size, may account for the reduced resistivities in the lithospheric mantle beneath the Magondi belt.

[35] As the 2-D inversion models, and the resistivity-depth profiles derived from them, are smooth, the transition from the lithosphere into the more conductive mantle asthenosphere below is not sharply defined. Relative lithosphere thickness variations between each terrane on the same profile can be determined from the observed systematic changes in bulk resistivity. The theoretical curves in Figure 10c provide a useful reference frame and indicate that an order of magnitude difference in electrical resistivity in the depth range of 100-150 km can be accounted for by a $\sim 40 \mathrm{~km}$ lithospheric thickness change. Based on that observation, Muller et al. [2009] conclude that with respect to the Eastern Kimberley Block, the Western Kimberley Block is associated with $\sim 30 \mathrm{~km}$ thinner lithosphere, the Rehoboth Terrane with $\sim 40 \mathrm{~km}$ thinner lithosphere, and the Damara/Ghanzi-Chobe Belt with $\sim 60 \mathrm{~km}$ thinner lithosphere. Similar relative differences for the lithospheric thickness can be defined for the Ghanzi-Chobe Belt with respect to the Zimbabwe craton (about 1 order of magnitude change in bulk resistivity), which indicates that the Ghanzi-Chobe Belt has a lithosphere about $\sim 40 \mathrm{~km}$ thinner than that of the Zimbabwe craton. The tentative inference that the lithosphere beneath the Magondi Mobile Belt might be about $\sim 60 \mathrm{~km}$ thinner has to be treated with caution as there is no data resolution for depths below $80-100 \mathrm{~km}$ at the sites directly above it, and poor resolution from neighboring sites. (Muller et al. [2009] suggest that the absolute depth to the base of the lithosphere can most reasonably be estimated as close to $\sim 220 \mathrm{~km}$ for the Eastern Kimberley Block, which results in absolute depths to the lithosphere of $190 \mathrm{~km}, 180 \mathrm{~km}$ and $160 \mathrm{~km}$ for the Western Kimberley Block, the Rehoboth Terrane and the Damara/ Ghanzi-Chobe Belt, respectively.) In the case of the GhanziChobe Belt (GCB) resistivity-depth profile presented here, an inflection point at about $180 \mathrm{~km}$ most likely marks the intersection of the conductive geotherm with the mantle adiabat, which, by definition, represents the thermal boundary layer (TBL) thickness of the lithosphere. The inflection point indicates that the lithosphere of the Ghanzi-Chobe Belt (at the ZIM line) is possibly $20 \mathrm{~km}$ thicker than about $1000 \mathrm{~km}$ further southwest (160 km by Muller et al. [2009]). Therefore, the absolute thickness of the lithosphere beneath the western extent of the Zimbabwe craton is deduced to be about $220 \mathrm{~km}$, and hence is of similar thickness as the Eastern Kimberley Block of the Kaapvaal craton in the study by Muller et al. [2009]. At a depth of about $200 \mathrm{~km}$ the cell thicknesses of the meshes of both the KIM-NAM and the ZIM profile are approximately $20 \mathrm{~km}$. Therefore, the estimate of depth to the lithosphere-asthenosphere boundary cannot be more accurate than $\pm 20 \mathrm{~km}$. Along strike variation in the thickness of the Damara/Ghanzi-Chobe belt lithosphere may not be significant given this uncertainty in thickness estimates.

[36] The Letlhakane and Orapa kimberlite pipes are about $150-200 \mathrm{~km}$ to the west of the ZIM line ("L" and "O" in Figures 1 and 4). Stiefenhofer et al. [1997] and Griffin et al. [2003] found that the pressure-temperature data of the kimberlite xenoliths from these pipes show a $\sim 41 \mathrm{~mW} / \mathrm{m}^{2}$ lithospheric geotherm at the time of pipe emplacement (at about $93 \mathrm{Ma}$ [Stiefenhofer et al., 1997]). This geotherm is similar to the one found at the Eastern Kimberley Block and corresponds to a thermal thickness of the lithosphere (defined by the intersect of the geotherm with the mantle adiabat) of about $220 \mathrm{~km}$ [Muller et al., 2009, and references therein]. Therefore, the geotherm is in principle also consistent with the $220 \mathrm{~km}$ thickness of the Zimbabwe craton. At Orapa and Letlhakane, xenoliths are only available to a maximum depth of about 200-205 km. Fertile lherzolites dominate in abundance above $120 \mathrm{~km}$ depth. Between 120 and $190 \mathrm{~km}$ depth, depleted harzburgites, with evidence of metasomatism, increase in abundance and below a very sharp transition at $190 \mathrm{~km}$ depth, sheared melt-metasomatized xenoliths dominate, with abundances of 80-100\% [Griffin et al., 2003]. Sheared melt metasomatism is often taken as an indication of proximity to the base of the lithosphere. Kennedy et al. [2002] proposed that sheared melt-metasomatized xenoliths are the result of transitory, high-strain rate deformation in a zone of noncoaxial strain localized at the base of the lithosphere. As it remains unclear as to which geological terrane the pipes of Orapa and Letlhakane are associated with (the Zimbabwe craton or the Magondi Mobile Belt), it may not be appropriate to use the geothermal information from the Letlhakane and Orapa pipes to support the lithospheric thickness of about $220 \mathrm{~km}$ suggested by the MT 2-D inversion result for the Zimbabwe craton (but as stated above, a $41 \mathrm{~mW} / \mathrm{m}^{2}$ is consistent with such a thickness). The geoelectric strike interpretation (Figure 4, suggested terrane boundary at region 3 near Gope) would, however, place both of these kimberlites within the western extension of the Zimbabwe craton lithosphere and the age of the lithosphere beneath Orapa is known to be Archean [Stiefenhofer et al., 1997], thus providing good support for the above inference. There is good evidence to suggest that the current thickness of the Eastern Kimberlite Block is the result of thinning/modification of lithosphere between the times of eruption of Group II ( 143-117 Ma) and Group I ( 108-75 Ma) kimberlites, and the Eastern Kimberlite Block lithosphere shows evidence of refertilization beneath $160 \mathrm{~km}$ depth [Griffin et al., 2003; Kobussen et al., 2008; Begg et al., 2009]. It is unknown if the Zimbabwe 


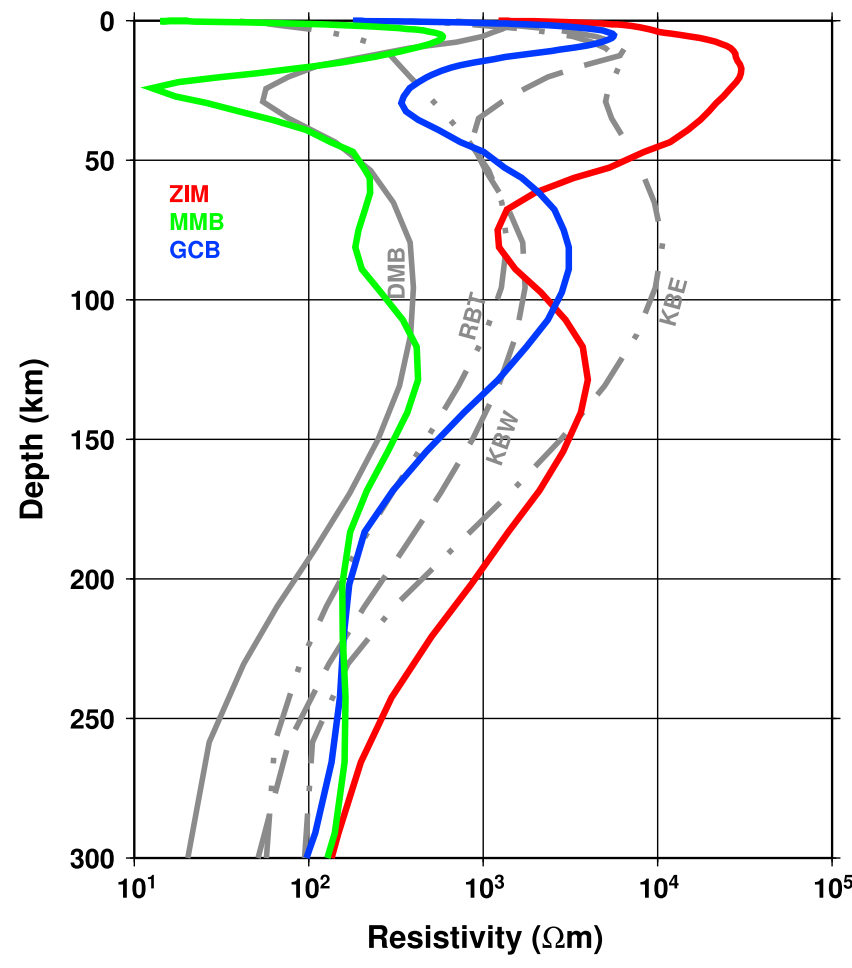

Figure 11. Average resistivity-depth profiles from SAMTEX data. This plot shows the average resistivity-depth curves from Figure 10 but also includes the crustal depths.

craton was originally thicker or not (only 1 age of kimberlite eruption similar to Group I), but it too is chemically refertilized below $180 \mathrm{~km}$ at Orapa [Griffin et al., 2003; Kobussen et al., 2008; Begg et al., 2009].

[37] Although the Ghanzi-Chobe Belt is Mesoproterozoic to Neoproterozoic and not Archean in age, the lithospheric mantle resistivity is relatively enhanced compared to the neighboring (older) Magondi Mobile Belt. Resistive lithospheric mantle was also observed beneath the Proterozoic Nipigon Embayment in Canada, which has been interpreted as a failed rift (I. Ferguson, University of Manitoba, personal communication, 2010). Modie [1996] also suggests that the Ghanzi-Chobe belt represents a failed intracontinental rift basin, which could be the reason for the enhanced lithospheric mantle resistivities. It cannot be defined from the results presented here whether the (compared to the Zimbabwe craton) reduced thickness of the lithosphere beneath the Ghanzi-Chobe belt reflects thinner lithosphere formed during the Pan-African Orogeny or tectonically thinned older lithosphere.

[38] The resistivity-depth profiles of the Zimbabwe craton and the unconstrained Magondi Mobile Belt show a strong decrease in bulk resistivity at depths of about 60 $100(120) \mathrm{km}$, which is not apparent in any of the resistivitydepth profiles of the KIM-NAM terranes nor the Ghanzi-Chobe Belt. Inspecting the KIM-NAM and ZIM models in Figures 10a and 10b, respectively, such a conductive zone does seem to exist in the Damara/Ghanzi-Chobe (DMB) and the Ghanzi-Chobe Belt (GCB) in lower crustal/ upper mantle depths above $50 \mathrm{~km}$ (and therefore is cut off in the resistivity versus depth profiles in Figure 10c). Figure 11 shows the average resistivity-depth profiles of Figure 10c including the crustal depth range. The full depth range reveals a conductive zone in nearly all the resistivity-depth profiles in middle to lower crustal depths that is already apparent in the 2-D inversion models in Figure 10. Ignoring the poorly constrained lithospheric mantle part of the Magondi resistivity-depth curve, the only resistivity-depth profile that exhibits a conductor below $50 \mathrm{~km}$ is the ZIM profile. That raises the question, what is different about the Zimbabwe craton relative to all the other terranes? The most obvious difference is the Okavango dike swarm at crustal depths. The very limited width of the dikes makes them more of an anisotropic feature than a normal 2-D structure at the MT scale. The Karoo-aged dolerites of the dike swarm are assumed to have a resistivity of $30,000 \Omega m$ [van Zijl, 2006], the dilatation of the dikes in that area is estimated to be $12.2 \%$ [Le Gall et al., 2005] and the principal anisotropic resistivities were derived based on Kirchhoff's Law. To examine the possible effect of the dike swarm, synthetic data, accounting for the dike swarm by using an anisotropic layer, were generated using the code by Pek and Verner [1997], then decomposed using the code of McNeice and Jones [2001] and finally inverted isotropically using the same inversion strategy as for the ZIM line data using WinGLink [Rodi and Mackie, 2001]. The test of 2-D isotropic inversion of the anisotropic dike model data strongly suggests that the appearance of the conductor below $50 \mathrm{~km}$ in the ZIM resistivitydepth profile and the deflected conductor in the 2-D inversion model are artifacts. The conductor is, in reality, located in the middle to lower crust, as is observed in all other resistivitydepth profiles (for more details see Miensopust [2010]). Under certain conditions, which we cannot exclude for the dike swarm, an anisotropic block might also influence the imaged thickness of the lithosphere (appears thicker than it is) and its resistivity estimates (appears more resistive) [Miensopust, 2010].

[39] Schwarz [1990] and Jones [1992] reviewed the nature of lower crustal conductors. As the porosity in rocks decreases with increasing depth, the hydrostatic pore volume should be reduced exponentially, leaving a residual isolated pore volume of highly saline fluids [Schwarz, 1990]. Therefore, a continuously increasing electrical resistivity with depth, with a change from electrolytic conduction in pore space to solid state electrical conduction in minerals, is expected, but MT studies have shown more conductive resistivities than expected [e.g., Shankland and Ander, 1983; Jones, 1992]. Candidates for lowering the electrical resistivity of the continental crust are fluids (free water with a high ionic content), free carbon (graphite) and other conducting minerals, such as magnetic oxides or sulphides, or partial melt [Schwarz, 1990; Jones, 1992]. If a zone of high electrical conductivity correlates with high seismic reflectivity in the lower crust, then the existence of fluids (especially in the deep, ductile crust) is the most likely cause [e.g., Jones, 1987, 1992]. However, there are no seismic reflection constraints available in the ZIM line area. Shankland and Ander [1983] found that free water of $0.01-0.1 \mathrm{vol} \%$ kept in fracture porosity would be sufficient to account for the observed lower resistivities. Schwarz [1990] notes that large interconnected fluid systems are required, and an effective pore pressure near zero is demanded over a geological timescale of at least 
several millions of years, which is highly unlikely as such a lithostatic fluid system would have unrealistically small hydraulic permeabilities.

[40] If interconnected graphite flakes or graphite grain coatings are present, the electrical resistivity decreases by several orders of magnitude [Nover et al., 1998], which accounts for large-scale resistivity anomalies in the continental crust in some settings [Duba and Shankland, 1982]. Other conducting minerals, such as those found in hydrothermal ore deposits, exist in the uppermost crust at temperatures below $400^{\circ} \mathrm{C}$ and pressures of less than $2 \mathrm{kbar}$ [Schwarz, 1990], and therefore are not very likely to be the cause of a lower crustal conductor of such a large spatial scale (other than the more localized conductors within the Magondi Mobile Belt). Melt or partial melt also can reduce the electrical resistivities, but for melt to occur in crustal depths, very high temperatures of above $700^{\circ} \mathrm{C}$ are required, which may only be found in tectonically active zones [Schwarz, 1990]. To account for large-scale conductors the melts must also be connected over large distances, which seems very unlikely for the Archean and Proterozoic terranes of and around the Zimbabwe craton. Also, there are no thermal effects visible on the surface, such as hot springs or uplift etc.

[41] No final conclusion regarding the cause of such a lower crustal conductor can be made in the case of the ZIM line, as additional information is required to support or rule out the different hypotheses, but graphite may be the explanation to favor.

\section{Conclusion}

[42] During the SAMTEX project, a broad region in South Africa, Botswana and Namibia has been investigated by deep-probing MT measurements. The area of interest for the work presented here is located in northeastern Botswana and is associate with the geological terranes of the Zimbabwe craton, the Magondi Mobile Belt and the Ghanzi-Chobe Belt. Other dominant features in the area are the giant mafic Okavango Dike Swarm, which has a strong magnetic field signature, and the Makgadikgadi pans, a huge salt pan complex that is most likely associated with a brine aquifer.

[43] The data set from the ZIM line crossing the terranes mentioned above exhibits strong lateral variation in penetration depth. Neighboring sites require periods with a difference of up to two decades to penetrate to a similar depth. Therefore, standard strike analysis using the Groom-Bailey decomposition technique for one frequency, or a frequency range, is not appropriate; instead one depth or depth range is required. Strike analyses based on depth ranges showed that the strike angle varies along the profile and with depth. Data sensing the lithospheric mantle generally prefer a strike angle of $35^{\circ} \mathrm{E}$ of north, whereas the crustal depths showed two dominant directions, $110^{\circ} \mathrm{E}$ of north for sites located on top of the Okavango dike swarm, and therefore consistent with its strike direction, and $55^{\circ} \mathrm{E}$ of north for all other sites.

[44] Maps of the most conductive direction for crustal and lithospheric depth ranges indicate that the position of the boundary between the Magondi Mobile Belt and the GhanziChobe Belt is in good agreement with the position inferred from SADC potential field data (but is about $60-80 \mathrm{~km}$ north of the far more regional-scale boundary defined by $W e b b[2009])$. Additionally, the southwestern boundary of the Zimbabwe craton may be located further to the west (somewhere close to Gope) than the terrane outline from the potential field data suggests.

[45] The crustal 2-D inversion (using the appropriate strike direction of $55^{\circ} \mathrm{E}$ of north) for the northern part of the ZIM line shows an about $600 \mathrm{~m}$ thick conductive near-surface layer identified as the brine aquifer associated with the Makgadikgadi pan complex. The boundary between the resistive Ghanzi-Chobe Belt to the north and the more heterogeneous Magondi Mobile Belt to the south was found to be dipping northward. A boundary between the Magondi Belt and the Zimbabwe craton could not be identified, but two middle to lower crustal conductors within the Magondi Belt were found in the area and depth range suggested by de Beer et al. [1975, 1976] and van Zijl and de Beer [1983] (the top of the conductors is at about $20 \mathrm{~km}$ depth in the crustal 2-D MT inversion model; located beneath ZIM121/ZIM122 and ZIM125). The cause of these conductors remains uncertain, but graphite and/or sulphide are favored.

[46] The whole ZIM profile was inverted using the lithospheric strike angle of $35^{\circ} \mathrm{E}$ of north. The crustal structures obtained from the focused inversion appear unchanged, and artifacts resulting from enforcing the lithospheric strike angle on the crustal data are not evident. The Zimbabwe craton and the Ghanzi-Chobe Belt show a resistive, thick lithospheric mantle. In the case of the Magondi Mobile Belt, the lithospheric mantle is poorly constrained in the 2-D inversion model, and it is therefore impossible to say with any certainty that a real structure is responsible for the higher conductivities observed there. Resistivity-depth profiles have been extracted from the 2-D inversion model and compared with the KIM-NAM resistivity-depth profiles from Muller et al. [2009] and theoretical geotherms. Based on the inflection point (which defines the thermal lithospheric thickness) of the resistivity-depth profile of the Ghanzi-Chobe Belt, its depth to the lithosphere-asthenosphere boundary is estimated at $180 \pm 20 \mathrm{~km}$. The relative difference in thickness between the Ghanzi-Chobe Belt lithospheric mantle and that of the Zimbabwe craton is about $40 \mathrm{~km}$ and, therefore, the depth to the lithosphere-asthenosphere boundary is estimated to be about $220 \pm 20 \mathrm{~km}$ for the Zimbabwe craton. Geotherms of $\sim 41 \mathrm{~mW} / \mathrm{m}^{2}$ at the Orapa and Letlhakane kimberlite pipes (about 150-200 km east of the ZIM line) also suggest a lithospheric thickness of about $220 \mathrm{~km}$ at the time of the emplacement of the pipes (at about $93 \mathrm{Ma}$ [Stiefenhofer et al., 1997, and references therein]). Geochemical analysis of xenoliths from these pipes (from a maximum depth of $205 \mathrm{~km}$, with no samples available from deeper depth) showed, at $190 \mathrm{~km}$, a sharp increase to $80-100 \%$ in the abundance of xenoliths showing melt-related metasomatism. Above $190 \mathrm{~km}$, fertile lherzolites and depleted harzburgites, both with some evidence of metasomatism, are the dominant rock types [Griffin et al., 2003]. The melt-metasomatized classes all show shearing [Griffin et al., 2003], which is often taken as indicating proximity to the base of the lithosphere. Kennedy et al. [2002] propose that sheared melt metasomatism is a result of transitory, high-strain rate deformation in a zone of noncoaxial strain localized at the base of the lithosphere.

[47] The Okavango dike swarm is a highly resistive crustal structure, and since the average dike width is about $17 \mathrm{~m}$, the dike swarm should be treated as anisotropic at the MT scale, 
rather than as a 2-D structure. In the 2-D inversion model, a conductor is imaged beneath the dike swarm at about 60 $70 \mathrm{~km}$ depth, whereas for the other terranes a conductor is apparent in middle to lower crustal depths. Tests by Miensopust [2010] with synthetic 2-D anisotropic data showed that an isotropic 2-D inversion of anisotropic data may cause the imaging of a crustal conductor incorrectly at lithospheric mantle depths. Effects on the lithospheric mantle resistivity estimates and the thickness of the lithosphere can also not be excluded.

[48] Acknowledgments. The authors wish to acknowledge the tremendous contribution made to this work by a number of people involved in several phases of data acquisition across southern Africa. We also acknowledge Phoenix Geophysics, the Geological Survey of Canada and the U.S. EMSOC for the access to instrumentation. In addition to the funding and logistical support provided by SAMTEX consortium members (Counci for Geoscience, Geological Surveys Botswana and Namibia, De Beers Group Services, Rio Tinto Exploration, and BHP Billiton), this work was also supported by research grants from National Science Foundation's Continental Dynamics program (USA, EAR-0309584 and EAR-0455242), the Department of Science and Technology (South Africa), and Science Foundation Ireland (Ireland, grant $05 / \mathrm{RFP} / \mathrm{GEO} 001$ ). We also thank the many farmers and landowners in Botswana, Namibia, and South Africa for their voluntary cooperation in allowing the deployment of MT stations on their properties Figures 1, 2, 4, 9, 10c, and 11 are plotted using the Generic Mapping Tool of Wessel and Smith [1991, 1998]. We thank Ian Ferguson and an anonymous reviewer for their critical and constructive comments on the manuscript, which helped to improve the paper.

\section{References}

Aubourg, C., G. Tshoso, B. Le Gall, H. Bertrand, J.-J. Tiercelin, A. B Kampunzu, J. Dyment, and M. Modisi (2008), Magma flow revealed by magnetic fabric in the Okavango giant dyke swarm, Karoo igneous province, northern Botswana, J. Volcanol. Geotherm. Res., 170 247-261.

Bailey, R. C., and R. W. Groom (1987), Decomposition of the magnetotelluric impedance tensor which is useful in the presence of channeling, in SEG Expanded Abstr., 6, 154-156.

Begg, G. C., et al. (2009), The lithospheric architecture of Africa: Seismic tomography, mantle petrology, and tectonic evolution, Geosphere, 5(1), 23-50, doi:10.1130/GES00179.1.

Berdichevsky, M. N., and V. I. Dmitriev (1976), Basic principles of interpretation of magnetotelluric sounding curves, in Geoelectric and Geothermal Studies, edited by A. Adam, pp. 165-221, Akad. Kiad, Budapest.

Berdichevsky, M. N., V. I. Dmitriev, and E. E. Pozdnjakova (1998), On two-dimensional interpretation of magnetotelluric soundings, Geophys. J. Int., 133, 585-606, doi:10.1046/j.1365-246X.1998.01333.x.

Bleeker, W. (2003), The late Archean record: A puzzle in ca. 35 pieces, Lithos, 71, 99-134.

Bostick, F. X. (1977), A simple almost exact method of MT analysis, Workshop on Electrical Methods in Geothermal Exploration, Contract 14080001-8-359, U.S. Geol. Surv., Reston, Va.

Caldwell, T. G., H. M. Bibby, and C. Brown (2004), The magnetotelluric phase tensor, Geophys. J. Int., 158, 457-469.

Chetty, D., and H. E. Frimmel (2000), The role of evaporites in the genesis of base metal sulphide mineralisation in the Northern Platform of the Pan-African Damara Belt, Namibia: Geochemical and fluid inclusion evidence from carbonate wall rock alteration, Miner. Deposita, 35(4), 364-376, doi:10.1007/s001260050247.

Constable, S. C., T. J. Shankland, and A. G. Duba (1992), The electrical conductivity of an isotropic olivine mantle, J. Geophys. Res., 97 3397-3404.

Corner, B. (2008), Crustal framework of Namibia derived from an integrated interpretation of geophysical and geological data, in The Geology of Namibia, vol. 1, Archaean to Mesoproterozoic, edited by R. M. Miller, chap. 2, pp. 2-1-2-19, Geol. Surv. Namibia, Windhoek, Namibia.

de Beer, J. H., D. I. Gough, and J. S. V. van Zijl (1975), An electrical conductivity anomaly and rifting in southern Africa, Nature, 255, 678-680.

de Beer, J. H., J. S. V. van Zijl, R. M. J. Huyssen, P. L. V. Hugo, S. J. Joubert, and R. Meyer (1976), A magnetometer array study in south-west Africa, Botswana and Rhodesia, Geophys. J. R. Astron. Soc., 45, 1-17. de Beer, J. H., R. M. J. Huyssen, S. J. Joubert, and J. S. V. van Zijl (1982), Magnetometer array studies and deep Schlumberger soundings in the Damara orogenic belt, south west Africa, Geophys. J. R. Astron. Soc., 70, 11-29.

de Wit, M., and J. Tinker (2004), Crustal structures across the central Kaapvaal craton from deep-seismic reflection data, S. Afr. J. Geol., 107, 185-206.

de Wit, M. J., C. Roering, R. J. Hart, R. A. Armstrong, E. Peberdy, and R. A. Hart (1992), Formation of an Archaean continent, Nature, 357, 553-562.

Duba, A. G., and T. J. Shankland (1982), Free carbon and electrical conductivity in the Earth's mantle, Geophys. Res. Lett., 9, 1271-1274.

Eaton, D. W., A. G. Jones, and I. J. Ferguson (2004), Lithospheric anisotropy structure inferred from collocated teleseismic and magnetotelluric observations: Great Slave Lake shear zone, northern Canada, Geophys. Res. Lett., 31, L19614, doi:10.1029/2004GL020939.

Eglington, B. M., and R. A. Armstrong (2004), The Kaapvaal craton and adjacent orogens, southern Africa: A geochronological database and overview of the geological development of the craton, S. Afr. J. Geol., $107,13-32$.

Elburg, M., and A. Goldberg (2000), Age and geochemistry of Karoo dolerite dykes from northeast Botswana, J. Afr. Earth Sci., 31, 539-554. Evans, R. L., G. Hirth, K. Baba, D. Forsyth, A. Chave, and R. Mackie (2005), Geophysical evidence from the MELT area for compositional controls on oceanic plates, Nature, 437, 249-252.

Gose, J., P. Reichart, G. Dollinger, and E. Schmädicke (2008), Water in natural olivine-Determined by proton-proton scattering analysis, Am. Mineral., 93, 1613-1619, doi:10.2138/am.2008.2835.

Griffin, W. L., S. Y. O'Reilly, L. M. Natapov, and C. G. Ryan (2003), The evolution of lithospheric mantle beneath the Kalahari craton and its margins, Lithos, 71, 215-241.

Griffin, W. L., S. Y. O'Reilly, B. J. Doyle, N. J. Pearson, H. Coopersmith, K. Kivi, V. Malkovets, and N. Pokhilenko (2004), Lithosphere mapping beneath the North American plate, Lithos, 77, 873-922.

Groom, R. W. (1988), The effects of inhomogeneities on magnetotellurics, Ph.D. thesis, Univ. of Toronto, Toronto, Ont., Canada.

Groom, R. W., and R. C. Bailey (1989), Decomposition of magnetotelluric impedance tensors in the presence of local three-dimensional galvanic distortion, J. Geophys. Res., 94, 1913-1925.

Grove, A. T. (1969), Landforms and climatic change in the Kalahari and Ngamiland, Geogr. J., 135, 191-212.

Hamilton, M. P., A. G. Jones, R. L. Evans, S. Evans, C. J. S. Fourie, X. Garcia, A. Mountford, J. E. Spratt, and the SAMTEX Team (2006), Electrical anisotropy of South African lithosphere compared with seismic anisotropy from shear-wave splitting analysis, Phys. Earth Planet. Inter. $158,226-239$.

Horstwood, M. S. A., R. W. Nesbitt, S. R. Noble, and J. F. Wilson (1999) $\mathrm{U}-\mathrm{Pb}$ zircon evidence for an extensive early Archean craton in Zimbabwe: A reassessment of the timing of craton formation, stabilization, and growth, Geology, 27, 707-710.

Hyndman, R. D., and P. M. Shearer (1989), Water in the lower continental crust: Modelling magnetotelluric and seismic reflection results, Geophys. J. Int., 98, 343-365.

Jacobs, J., S. Pisarevsky, R. J. Thomas, and T. Becker (2008), The Kalahari craton during the assembly and dispersal of Rodinia, Precambrian Res., 160, 142-158.

Ji, S., S. Rondenay, M. Mareschal, and G. Senechal (1996), Obliquity between seismic and electrical anisotropies as a potential indicator of movement sense for ductile shear zones in the upper mantle, Geology, 24, 1033-1036.

Jones, A. G. (1981), On a type classification of lower crustal layers under Precambrian regions, J. Geophys., 49, 226-233.

Jones, A. G. (1983a), On the equivalence of the "Niblett" and "Bostick" transformations in the magnetotelluric method, J. Geophys., 53, 72-73.

Jones, A. G. (1983b), The problem of current channelling: A critical review, Geophys. Surv., 6, 79-122.

Jones, A. G. (1987), MT and reflection: An essential combination, Geophys. J. R. Astron. Soc., 89, 7-18.

Jones, A. G. (1992), Electrical conductivity of the continental lower crust, in Continental Lower Crust, edited by D. M. Fountain, R. J. Arculus, and R. W. Kay, pp. 81-143, Elsevier, Amsterdam.

Jones, A. G. (1993), Electromagnetic images of modern and ancient subduction zones, in Plate Tectonic Signatures in the Continental Lithosphere, vol. 219, edited by A. G. Green et al., pp. 29-45, Elsevier, Amsterdam.

Jones, A. G. (1999), Imaging the continental upper mantle using electromagnetic methods, Lithos, 48, 57-80. 
Jones, A. G. (2006), Electromagnetic interrogation of the anisotropic Earth: Looking into the Earth with polarized spectacles, Phys. Earth Planet. Inter., 158, 281-291.

Jones, A. G., and J. A. Craven (1990), The North American Central Plains conductivity anomaly and its correlation with gravity, magnetic, seismic, and heat flow data in Saskatchewan, Canada, Phys. Earth Planet. Inter., 60, 169-194.

Jones, A. G., and R. W. Groom (1993), Strike angle determination from the magnetotelluric tensor in the presence of noise and local distortion: Rotate at your peril!, Geophys. J. Int., 113, 524-534.

Jones, A. G., and H. Jödicke (1984), Magnetotelluric transfer function estimation improvement by a coherence-based rejection technique, paper presented at 54th Annu. Meet., Soc. of Explor. Geophys., Atlanta, Ga.

Jones, A. G., A. D. Chave, G. Egbert, D. Auld, and K. Bahr (1989), A comparison of techniques for magnetotelluric response function estimation, J. Geophys. Res., 94, 14,201-14,213.

Jones, A. G., J. A. Craven, G. A. McNeice, I. J. Ferguson, T. Boyce, C. Farquharson, and R. G. Ellis (1993), North American Central Plains conductivity anomaly within the Trans-Hudson orogen in northern Saskatchewan, Geology, 21, 1027-1030.

Jones, A. G., T. J. Katsube, and P. Schwann (1997), The longest conductivity anomaly in the world explained: Sulphides in the fold hinges causing very high electrical anisotropy, J. Geomagn. Geoelectr., 49, $1619-1629$.

Jones, A. G., D. Snyder, S. Hanmer, I. Asudeh, D. White, D. Eaton, and G. Clarke (2002), Magnetotelluric and teleseismic study across the Snowbird tectonic zone, Canadian shield: A Neoarchean mantle suture?, Geophys. Res. Lett., 29(17), 1829, doi:10.1029/2002GL015359.

Jones, A. G., X. Garcia, R. L. Evans, E. H. Stettler, and F. W. Arnott (2005a), Towards understanding Archean tectonic processes through electromagnetic imaging, Proposal 05/RFP/GEO0001, Sci. Found. Ireland, Dublin, Ireland.

Jones, A. G., J. Ledo, and I. J. Ferguson (2005b), Electromagnetic images of the Trans-Hudson orogen: The North American Central Plains anomaly revealed, Can. J. Earth Sci., 42, 457-478.

Jones, A. G., et al. (2009a), Area selection for diamonds using magnetotellurics: Examples from southern Africa, Lithos, 112S, 83-92, doi:10.1016/ j.lithos.2009.06.011.

Jones, A. G., R. L. Evans, and D. W. Eaton (2009b), Velocity-conductivity relationships for the mantle mineral assemblages in archean cratonic lithosphere based on a review of laboratory data and Hashin-Shtrikman extremal bounds, Lithos, 109, 131-143, doi:10.1016/j.lithos.2008.10. 014.

Jourdan, F., G. Féraud, H. Bertrand, A. B. Kampunzu, G. Tshoso, B. Le Gall, J. J. Tiercelin, and P. Capiez (2004), The Karoo triple junction questioned: Evidence from Jurassic and Proterozoic ${ }^{40} \mathrm{Ar} /{ }^{39} \mathrm{Ar}$ ages and geochemistry of the giant Okavango dyke swarm (Botswana), Earth Planet. Sci. Lett., 222, 989-1006.

Jourdan, F., G. Féraud, H. Bertrand, M. K. Watkeys, A. B. Kampunzu, and B. Le Gall (2006), Basement control on dyke distribution in large igneous provinces: Case study of the Karoo triple junction, Earth Planet. Sci. Lett., 241, 307-322.

Kamona, A. F., J. Lévêque, G. Friedrich, and U. Haack (1999), Lead isotopes of the carbonate-hosted Kabwe, Tsumeb, and Kipushi Pb-Zn$\mathrm{Cu}$ sulphide deposits in relation to Pan African orogenesis in the Damaran-Lufilian Fold Belt of central Africa, Mineral. Deposita, 34(3), 273-283, doi:10.1007/s001260050203.

Karato, S. (1990), The role of hydrogen in the electrical conductivity of the upper mantle, Nature, 347, 272-273.

Karato, S. (2006), Remote sensing of hydrogen in Earth's mantle: Water in nominally anhydrous minerals, Rev. Mineral. Geochem., 62, 343-375.

Kennedy, L. A., J. K. Russell, and M. G. Kopylova (2002), Mantle shear zones revisited: The connection between the cratons and mantle dynamics, Geology, 30, 419-422.

Kobussen, A. F., W. L. Griffin, S. Y. O’Reilly, and S. R. Shee (2008), Ghosts of lithospheric past: Imaging an evolving lithospheric mantle in southern Africa, Geology, 36, 515-518

Kusky, T. M. (1998), Tectonic setting and terrane accretion of the Archean Zimbabwe craton, Geology, 26, 163-166.

Kusky, T. M., and A. Polat (1999), Growth of granite-greenstone terranes at convergent margins, and stabilization of Archean cratons, Tectonophysics, 305, 43-73.

Ledo, J., P. Queralt, A. Marti, and A. G. Jones (2002), Two-dimensiona interpretation of three-dimensional magnetotelluric data: An example of limitations and resolution, Geophys. J. Int., 150, 127-139.

Le Gall, B., et al. (2002), ${ }^{40} \mathrm{Ar} /{ }^{39} \mathrm{Ar}$ geochronology and structural data from the giant Okavango and related dyke swarms, Karoo igneous province, Botswana, Earth Planet. Sci. Lett., 202, 595-606.
Le Gall, B., G. Tshoso, J. Dyment, A. B. Kampunzun, F. Jourdan, G. Féraud, H. Bertrand, C. Aubourg, and W. Vétel (2005), The Okavango giant mafic dyke swarm (NE Botswana): Its structural significance within the Karoo Large Igneous Province, J. Struct. Geol., 27, 2234-2255.

Leyshon, P. R., and F. P. Tennick (1988), The Proterozoic Magondi mobile belt in Zimbabwe-A review, S. Afr. J. Geol., 91, 114-131.

Majaule, T., R. E. Hanson, R. M. Key, S. J. Singletary, M. W. Martin, and S. A. Bowring (2001), The Magondi Belt in northeast Botswana: Regional relations and new geochronological data from the Sua Pan area, J. Afr. Earth Sci., 32, 257-267.

Maumus, J., N. Bagdassarov, and H. Schmeling (2005), Electrical conductivity and partial melting of mafic rocks under pressure, Geochim. Cosmochim. Acta, 69(19), 4703-4718.

McCourt, S., A. Kampunzu, Z. Bagai, and R. Armstrong (2004), The crustal architecture of Archaean terranes in northeastern Botswana, $S$. Afr. J. Geol., 107, 146-158.

McNeice, G. W., and A. G. Jones (2001), Multisite, multifrequency tensor decomposition of magnetotelluric data, Geophysics, 66, 158-173.

Miensopust, M. P. (2010), Multidimensional magnetotellurics: A 2D case study and a 3D approach to simultaneously invert for resistivity structure and distortion parameters, Ph.D. thesis, Fac. of Sci., Dep. of Earth and Ocean Sci., Natl. Univ. of Ireland, Galway, Ireland.

Modie, B. N. J. (1996), Depositional environments of the Meso- to Neoproterozoic Ghanzi-Chobe belt, northwest Botswana, J. Afr. Earth Sci., 22 255-268.

Muller, M. R., et al. (2009), Lithospheric structure, evolution and diamond prospectivity of the Rehoboth Terrane and the western Kaapvaal craton, southern Africa: Constraints from broadband magnetotellurics, Lithos, 112S, 93-105, doi:10.1016/j.lithos.2009.06.023.

Niblett, E. R., and C. Sayn-Wittgenstein (1960), Variation of electrical conductivity with depth by the magneto-telluric method, Geophysics, 25 , 998-1008.

Nover, G., S. Heikamp, H. J. Meurer, and D. Freund (1998), In-situ electrical conductivity and permeability of mid-crustal rocks from the KTB drilling: Consequences for high conductive layers in the Earth crust, Surv. Geophys., 19, 73-85.

Padilha, A. L., I. Vitorello, M. B. Padua, and M. S. Bologna (2006), Lithospheric and sublithospheric anisotropy beneath central-southeastern Brazil constrained by long period magnetotelluric data, Phys. Earth Planet. Inter., 158, 190-209.

Parker, R. L. (1980), The inverse problem of electromagnetic induction: Existance and construction of solutions based on incomplete data, J. Geophys. Res., 85, 4421-4425.

Parker, R. L. (1982), The existence of a region inaccessible to magnetotelluric sounding, Geophys. J. R. Astron. Soc., 68, 165-170.

Parker, R. L., and K. A. Whaler (1981), Numerical methods for establishing solutions to the inverse problem of electromagnetic induction, J. Geophys. Res., 86, 9574-9584.

Pek, J., and T. Verner (1997), Finite-difference modelling of magnetotelluric fields in two-dimensional anisotropic media, Geophys. J. Int., 128, 505-521.

Prave, A. R. (1996), Tale of three cratons: Tectonostratigraphic anatomy of the Damara orogen in northwestern Namibia and the assembly of Gondwana, Geology, 24, 1115-1118.

Read, G. H., and A. J. A. B. Janse (2009), Diamonds: Exploration, mines and marketing, Lithos, 112, 1-9, doi:10.1016/j.lithos.2009.03.024.

Reeves, C. V. (1985), The Kalahari Desert, central southern Africa: A case history of regional gravity and magnetic exploration, in The Utility of Regional Gravity and Magnetic Anomaly Maps, edited by W. J. Hinze, pp. 144-153, Soc. of Explor. Geophys., Tulsa, Okla.

Ritter, O., U. Weckmann, T. Vietor, and V. Haak (2003), A magnetotelluric study of the Damara Belt in Namibia-1. Regional scale conductivity anomalies, Phys. Earth Planet. Inter., 138, 71-90.

Rodi, W., and R. L. Mackie (2001), Nonlinear conjugate gradients algorithm for 2-D magnetotelluric inversion, Geophysics, 66, 174-187.

Schwarz, G. (1990), Electrical conductivity of the Earth's crust and upper mantle, Surv. Geophys., 11, 133-161.

Shankland, T. J., and M. E. Ander (1983), Electrical conductivity, temperatures, and fluids in the lower crust, J. Geophys. Res., 88, 9475-9484.

Singletary, S. J., R. E. Hanson, M. W. Martin, J. L. Crowley, S. A. Bowring, R. M. Key, L. V. Ramokate, B. B. Direng, and M. A. Krol (2003), Geochronology of basement rocks in the Kalahari Desert, Botswana, and implications for regional Proterozoic tectonics, Precambrian Res., 121, 47-71.

Spratt, J. E., A. G. Jones, V. A. Jackson, L. Collins, and A. Avdeeva (2009), Lithospheric geometry of the Wopmay orogen from a Slave craton to Bear Province magnetotelluric transect, J. Geophys. Res., 114 B01101, doi:10.1029/2007JB005326. 
Stiefenhofer, J., K. S. Viljoen, and J. S. Marsh (1997), Petrology and geochemistry of peridotite xenoliths from the Letlhakane kimberlites, Botswana, Contrib. Min. Petrol., 127, 147-158.

ten Grotenhuis, S. M., M. R. Drury, C. J. Peach, and C. J. Spiers (2004), Electrical properties of fine-grained olivine: Evidence for grain boundary transport, J. Geophys. Res., 109, B06203, doi:10.1029/2003JB002799.

Tinker, J. H., M. J. de Wit, and L. H. Royden (2004), Old, strong continental lithosphere with weak Archaean margin at $\sim 1.8 \mathrm{Ga}$, Kaapvaal craton, South Africa, S. Afr. J. Geol., 107, 255-260.

Treloar, P. J. (1988), The geological evolution of the Magondi mobile belt, Zimbabwe, Precambrian Res., 38, 55-73.

Treloar, P. J., and J. D. Kramers (1989), Metamorphism and geochronology of granulites and migmatitic granulites from the Magondi mobile belt, Zimbabwe, Precambrian Res., 45, 277-289.

Unsworth, M., G. Egbert, and J. Booker (1999), High-resolution electromagnetic imaging of the San Andreas fault in central California, J. Geophys. Res., 104, 1131-1150.

van Reenen, D. D., J. M. Barton Jr., C. Roering, C. A. Smith, and J. F. van Schalkwyk (1987), Deep crustal response to continental collision: The Limpopo belt of southern Africa, Geology, 15, 11-14.

van Zijl, J. S. V. (2006), A review of the resistivity structure of the Karoo supergroup, South Africa, with emphasis on the dolerites: A study in anisotropy, S. Afr. J. Geol., 109, 315-328.

van Zijl, J. S. V., and J. H. de Beer (1983), Electrical structure of the Damara orogen and its tectonic significance, Spec. Publ. Geol. Soc. S. Afr., 11, 369-379.
Wannamaker, P. E., G. W. Hohmann, and S. H. Ward (1984), Magnetotelluric responses of three-dimensional bodies in layered earths, Geophysics, 49, 1517-1533.

Webb, S. J. (2009), Southern African tectonics from potential field interpretation, Ph.D. thesis, Univ. of the Witwatersrand, Johannesburg, South Africa.

Wessel, P., and W. H. F. Smith (1991), Free software help map and display data, Eos Trans. $A G U, 72,441$.

Wessel, P., and W. H. F. Smith (1998), New, improved version of the Generic Mapping Tools released, Eos Trans. AGU, 79, 579.

Wilson, J. F. (1979), A preliminary reappraisal of the Rhodesian basement complex, Spec. Publ. Geol. Soc. S. Afr., 5, 1-23.

Xu, Y. S., and T. J. Shankland (1999), Electrical conductivity of orthopyroxene and its high pressure phases, Geophys. Res. Lett., 26, 2645-2648.

Xu, Y. S., T. J. Shankland, and A. G. Duba (2000), Pressure effect on electrical conductivity of mantle olivine, Phys. Earth Planet. Inter., 118, 149-161

R. L. Evans, Department of Geology and Geophysics, Woods Hole Oceanographic Institution, Clark 263, 266 Woods Hole Rd., Woods Hole, MA 02543-1542, USA. (revans@whoi.edu)

X. Garcia, Unitat de Tecnologia Marina, CSIC, Pg. Maritim de la Barcelonela 37-49, E-08003 Barcelona, Spain. (xgarcia@cmima.csic.es)

A. G. Jones, M. P. Miensopust, and M. R. Muller, Geophysics Section, School of Cosmic Physics, Dublin Institute for Advanced Studies, 5 Merrion Sq., Dublin 2, Ireland. (alan@cp.dias.ie; marion@cp.dias.ie; mark.muller@dias.ie) 